Article

\title{
Analyzing the Effect of Baking on the Flavor of Defatted Tiger Nut Flour by E-Tongue, E-Nose and HS-SPME-GC-MS
}

\author{
Chunbo Guan $\left.{ }^{1} \mathbb{(}\right)$, Tingting Liu ${ }^{1, *}$, Quanhong $\mathrm{Li}^{2, *}$, Dawei Wang ${ }^{1}$ and Yanrong Zhang ${ }^{1}$ \\ 1 School of Food Science and Engineering, Jilin Agricultural University, Changchun 130118, China; \\ guanb1112@163.com (C.G.); wangdawei@jlau.edu.cn (D.W.); zhangyanrong0044@jlau.edu.cn (Y.Z.) \\ 2 School of Food Science and Nutritional Engineering, China Agricultural University, Beijing 100083, China \\ * Correspondence: liutingting@jlau.edu.cn (T.L.); liquanhong66@163.com (Q.L.)
}

check for updates

Citation: Guan, C.; Liu, T.; Li, Q.; Wang, D.; Zhang, Y. Analyzing the Effect of Baking on the Flavor of Defatted Tiger Nut Flour by

E-Tongue, E-Nose and HS-SPME-GC-MS. Foods 2022, 11, 446 https://doi.org/10.3390/ foods11030446

Academic Editor: Susana Casal

Received: 5 January 2022

Accepted: 30 January 2022

Published: 2 February 2022

Publisher's Note: MDPI stays neutral with regard to jurisdictional claims in published maps and institutional affiliations.

Copyright: (C) 2022 by the authors. Licensee MDPI, Basel, Switzerland. This article is an open access article distributed under the terms and conditions of the Creative Commons Attribution (CC BY) license (https:// creativecommons.org/licenses/by/ $4.0 /)$.

\begin{abstract}
In order to screen for a proper baking condition to improve flavor, in this experiment, we analyzed the effect of baking on the flavor of defatted tiger nut flour by electronic tongue (E-tongue), electronic nose (E-nose) and headspace solid-phase microextraction gas chromatographymass spectrometry (HS-SPME-GC-MS). According to E-tongue and E-nose radar plots and principal component analysis (PCA), baking can effectively change the taste and odor of defatted tiger nut flour, and the odors of samples with a baking time of $>8$ min were significantly different from the original odor of unbaked flour. Moreover, bitterness and astringency increased with longer baking times, and sweetness decreased. HS-SPME-GC-MS detected a total of 68 volatile organic compounds (VOCs) in defatted tiger nut flour at different baking levels, and most VOCs were detected at $8 \mathrm{~min}$ of baking. Combined with the relative odor activity value (ROAV) and heat map analysis, the types and contents of key flavor compounds were determined to be most abundant at 8 min of baking; 3-methyl butyraldehyde (fruity and sweet), valeraldehyde (almond), hexanal (grassy and fatty), and 1-dodecanol, were the key flavor compounds. 2,5-dimethyl pyrazine, and pyrazine, 2-ethylalkyl-3,5-dimethyl- added nutty aromas, and 1-nonanal, 2-heptanone, octanoic acid, bicyclo [3.1.1] hept-3-en-2-ol,4,6,6-trimethyl-, and 2-pentylfuran added special floral and fruity aromas.
\end{abstract}

Keywords: defatted tiger nut flour; flavor; E-tongue; E-nose; HS-SPME-GC-MS; baking

\section{Introduction}

Tiger nut (Cyperus esculentus L.), also known as wild chestnut, underground walnut, etc., is a highly efficient and high-quality edible oil crop that is drought-resistant [1]. It originated in North Africa and the Mediterranean, and is widely cultivated in Spain, Italy, South Africa, and other regions [2]. It has high oil content and oil quality, and can be widely planted as a raw material for edible oil $[3,4]$. As a by-product of tiger nut oil production, defatted tiger nut flour contains many nutrients such as starch, sugar, dietary fiber, protein, vitamins, and minerals [5,6]. It is a raw material for low-fat food with high nutritional value. It can be used to make defatted beverages and pastries that conform to the modern desire for a low-fat and healthy diet. The oil contains much flavor [7], but as most of the oil in the tiger nut is extracted, the fat-soluble flavor compounds are removed in the production of flour, resulting in the reduced flavor of the defatted flour.

Baking is an efficient and rapid means of flavor enhancement. It can make up for the shortcomings of the reduced flavor after defatting, thus meeting consumer preference and improving the breadth of application. During baking, carbonyl compounds and amides trigger the Maillard reaction, Streker degradation, and caramelization reaction, to produce aldehydes, ketones, pyrazines, heterocyclics, etc. [8-10]. Too much baking will destroy amino acids and sugars and convert the dominant flavor to a burnt one and cause bitterness [11]. The defatted tiger nut flour contains abundant sugars and amino acids, which can be used as suitable flavor precursors $[5,10]$. Proper baking condition can retain 
the flavor of defatted tiger nut flour, increasing the sweet, caramel, and nutty flavors as well as special aromas such as floral and fruity [12]. This makes up for the deficiency of reduced flavor of the flour after defatting, increasing its popularity among consumers and the range of applications. At the same time, baking can sterilize the flour and extend its shelf life, and is thus conducive to its preservation and transportation [13].

E-tongue can digitize taste and effectively distinguish the taste of a sample through the detection of sourness, bitterness, astringency, saltiness, umami, and sweetness [14]. The E-nose utilizes varied "odor fingerprints" for VOCs, and it can precisely identify the differences among various samples [15]. HS-SPME-GC-MS can extract, separate, and detect sample odors and qualitatively and quantitatively assess VOCs [16]. This experiment is the first to analyze the taste and odor of defatted tiger nut flour by E-tongue, E-nose and HS-SPME-GC-MS, and screen for the baking conditions that improve its flavor, thus realizing its high-value utilization as a food raw material. At the same time, with this work, we offer a theoretical basis for the flavor improvement of starchy raw materials such as defatted tiger nut flour, through baking.

\section{Materials and Methods}

\subsection{Sample Preparation}

Tiger nut flour was passed through a $0.42 \mathrm{~mm}$ (60-mesh) screen and was added to a tank for supercritical $\mathrm{CO}_{2}$ extraction, with the following parameters: extraction pressure $25 \mathrm{MPa}$, extraction temperature $45^{\circ} \mathrm{C}$, and extraction time $3 \mathrm{~h}$.

The heat of the oven was adjusted to $150^{\circ} \mathrm{C}$ and preheated for $10 \mathrm{~min}$. Defatted tiger nut flour was spread $3 \mathrm{~mm}$ thick on a baking sheet, placed it the oven, and baked for $0,4,8$, 12,16 , or $20 \mathrm{~min}$.

\subsection{HS-SPME}

Defatted tiger nut flour $(0.8 \mathrm{~g})$ was added to a headspace bottle, which was immediately sealed with a latex cap and equilibrated at $50{ }^{\circ} \mathrm{C}$ for $30 \mathrm{~min}$. The SPME fiber $(50 / 30 \mu \mathrm{m}$ DVB/CAR/PDMS, Supelco, PA, USA) was inserted and pushed out, absorbed for $30 \mathrm{~min}$, slowly retracted, and then immediately inserted in the gas chromatograph inlet, slowly pushed out the fiber head, and desorbed at $250{ }^{\circ} \mathrm{C}$ for $5 \mathrm{~min}$. GC-MS analysis was then performed.

\subsection{GC-MS Analysis}

The VOCs were separated in an INNOW-WAX capillary column $(30 \mathrm{~m} \times 0.25 \mathrm{~mm} \times$ $0.25 \mu \mathrm{m}$, Agilent J\&W, Santa Clara, CA, USA). The temperature conditions were as follows: initial temperature of $40{ }^{\circ} \mathrm{C}$ was held for $3 \mathrm{~min}$; raised to $70{ }^{\circ} \mathrm{C}$ at a rate of $3{ }^{\circ} \mathrm{C} / \mathrm{min}$, held for $2 \mathrm{~min}$; raised to $170{ }^{\circ} \mathrm{C}$ at a rate of $5{ }^{\circ} \mathrm{C} / \mathrm{min}$, held for $2 \mathrm{~min}$; and raised to $230{ }^{\circ} \mathrm{C}$ at a rate of $8^{\circ} \mathrm{C} / \mathrm{min}$, then held for $5 \mathrm{~min}$. The carrier gas was helium $(99.99 \%)$, the flow rate was $1 \mathrm{~mL} / \mathrm{min}$, the pressure was $112.0 \mathrm{kPa}$, the split ratio was 10:1, and the gas chromatograph inlet temperature was $250{ }^{\circ} \mathrm{C}$. The ion source was EI at an energy of $70 \mathrm{eV}$, the MS transfer line temperature was $230{ }^{\circ} \mathrm{C}$, the ion source temperature was $240{ }^{\circ} \mathrm{C}$, a solvent delay of 3 min was used, and a full scan mode was adopted across the $m / z$ range of 35 to 500 . The VOCs were qualitatively analyzed by NIST mass spectrometry database. Results were accepted when matching and reverse matching values were above 800 . Quantitative analysis was based on the area normalization method, removing the erosion of SPME fiber and the capillary column and unidentified peaks. Only the identified peaks were used for normalization.

\subsection{Relative Odor Activity Value (ROAV)}

With reference to Yi C.P. [17], the ROAV method was used to determine the key volatile compounds in defatted tiger nut flour. The compound with the greatest contribution to 
the sample's odor was assigned ROAV $=100$, and the other compounds' ROAVs were calculated as follows:

$$
\mathrm{ROAV} \approx \frac{C_{A}}{C_{\text {stan }}} \times \frac{T_{\text {stan }}}{T_{A}} \times 100
$$

where $C_{A}$ and $T_{A}$ are the relative content and threshold of compound $A$, respectively. $C_{\text {stan }}$, $T_{\text {stan }}$ are the relative content and threshold of the compound that contributed the most to the main odor of the sample.

\subsection{E-Nose Analysis}

Defatted tiger nut flour (1 g) was placed into a $20 \mathrm{~mL}$ headspace bottle and balanced at $(25 \pm 1){ }^{\circ} \mathrm{C}$ for $0.5 \mathrm{~h}$. The PNE3 electronic nose (PEN3 Airsence, Schwerin, Germany) was used for detection. Table A1 lists the sensor array elements of the E-nose (Table A1, Appendix A). The measurement conditions were as follows: internal flow rate of $400 \mathrm{~mL} / \mathrm{min}$, injection flow rate of $100 \mathrm{~mL} / \mathrm{min}$, cleaning time of $80 \mathrm{~s}$, sample preparation time of $5 \mathrm{~s}$, and detection time of $60 \mathrm{~s}$.

\subsection{E-Tongue Analysis}

With reference to Cai W.C. [18], analysis was performed on the defatted tiger nut flour using the Taste-Sensing System SA 402B (Intelligent Sensor Technology Co., Ltd., Atsugi, Japan). Table A2 lists the sensor array elements of the E-tongue (Table A2, Appendix B). Defatted tiger nut flour $(10 \mathrm{~g})$ was added to $100 \mathrm{~mL}$ of $100{ }^{\circ} \mathrm{C}$ deionized water and soaked for $30 \mathrm{~min}$. The mixture was centrifuged at $3800 \times g$ for $20 \mathrm{~min}$ at $20^{\circ} \mathrm{C}$, then the supernatant was withdrawn and filtered. The filtrate was used for E-tongue analysis after calibration and diagnosis of the sensor at $(25 \pm 1){ }^{\circ} \mathrm{C}$. Each sample was tested for six tastes.

\subsection{Statistical Analysis}

E-nose and E-tongue principal component analysis (PCA) and the radar chart were calculated using Origin 2018. Analysis of variance (ANOVA) was used to analyze the differences among samples at a significance level of 0.05 by SPSS 25 (IBM, Armonk, NY, USA). The heat map clustering analysis was performed using the TB tools. All experiments were repeated three times.

\section{Results}

\subsection{VOCs in Defatted Tiger Nut Flour}

Reasonable baking can effectively improve the flavor of defatted tiger nut flour. Some studies have shown that the Maillard reaction temperature is around $100{ }^{\circ} \mathrm{C}$ and the caramelization reaction temperature is around $120^{\circ} \mathrm{C}$ [19]. If the baking temperature is too low, the material will take a long time to bake, resulting in low baking efficiency and high processing energy consumption. If the baking temperature is too high, it will destroy nutrients such as amino acids and sugars. Furthermore, the reaction rate will be too fast and difficult to control during processing. With overbaking, it is easy for the sample to lose its original odor and develop a burnt odor and bitterness [20]. Therefore, in this experiment, we controlled the baking temperature at $150{ }^{\circ} \mathrm{C}$. It can be seen from Table 1, Figure A1 (Appendix C) and Table A3 (Appendix D), a total of 68 volatile flavor compounds were detected in defatted tiger nut flour with six different baking times. There were 7 aldehydes, 15 alcohols, 6 ketones, 15 esters, 7 acids, 2 olefins, 2 alkanes, 5 pyrazines, and 9 other compounds. The volatile flavor compounds of the baked defatted tiger nut flour increased significantly in types and richness, but varied significantly with different baking times. After baking, the relative content of hexanal and 1-hexanol decreased, indicating that grassy and fruity aromas decreased [21]. Furthermore, the relative content of ketones and pyrazines increased, indicating that flowery, sweet, and nutty aromas increased [22]. 
Table 1. VOCs in defatted tiger nut flour.

\begin{tabular}{|c|c|c|c|c|c|c|c|c|c|c|c|c|c|}
\hline \multirow{2}{*}{ Count } & \multirow{2}{*}{ RT } & \multirow{2}{*}{ Compounds } & \multirow{2}{*}{ RI } & \multirow{2}{*}{ Formula } & \multirow{2}{*}{$\begin{array}{c}\text { Molecular } \\
\text { Ion Mass } \\
(\mathrm{M}+)\end{array}$} & \multirow{2}{*}{ CAS\# } & \multicolumn{6}{|c|}{ Relative Content/(\%) } & \multirow{2}{*}{$\begin{array}{l}\text { Qualitative } \\
\text { Method }\end{array}$} \\
\hline & & & & & & & $0 \mathrm{~min}$ & $4 \mathrm{~min}$ & $8 \min$ & $12 \mathrm{~min}$ & $16 \mathrm{~min}$ & $20 \mathrm{~min}$ & \\
\hline & & Aldehydes & & & & & & & & & & & \\
\hline 1 & 3.14 & 3-Methylbutyraldehyde & 652 & $\mathrm{C}_{5} \mathrm{H}_{10} \mathrm{O}$ & 86.07 & $590-86-3$ & $2.65 \pm 0.80^{c}$ & $17.15 \pm 1.73^{a}$ & $7.30 \pm 0.25^{b}$ & $17.32 \pm 0.25^{\mathrm{a}}$ & $7.18 \pm 0.77^{b}$ & $7.40 \pm 0.77^{b}$ & MS, RI \\
\hline 2 & 4.21 & Valeraldehyde & 699 & $\mathrm{C}_{5} \mathrm{H}_{10} \mathrm{O}$ & 86.07 & $110-62-3$ & $2.76 \pm 0.40^{\mathrm{cd}}$ & $3.07 \pm 0.28^{c}$ & $1.86 \pm 0.17^{\mathrm{d}}$ & $5.28 \pm 0.65^{\mathrm{a}}$ & $4.55 \pm 1.31^{\mathrm{ab}}$ & $3.48 \pm 0.29 \mathrm{bc}$ & MS, RI \\
\hline 4 & 7.23 & 2-Methyl-2-butenal & 745 & $\mathrm{C}_{5} \mathrm{H}_{8} \mathrm{O}$ & 84.06 & 497-03-0 & ND & ND & ND & ND & $4.64 \pm 0.18^{\mathrm{a}}$ & ND & MS, RI \\
\hline 5 & 14.91 & Octanal & 1003 & $\mathrm{C}_{8} \mathrm{H}_{16} \mathrm{O}$ & 128.12 & $124-13-0$ & $2.09 \pm 0.16^{\mathrm{a}}$ & ND & $1.34 \pm 0.09^{b}$ & $2.38 \pm 0.28$ a & ND & ND & MS, RI \\
\hline 6 & 19.37 & 1-Nonanal & 1104 & $\mathrm{C}_{9} \mathrm{H}_{18} \mathrm{O}$ & 142.13 & $124-19-6$ & $1.71 \pm 0.12^{\mathrm{a}}$ & ND & $1.03 \pm 0.07^{c}$ & $1.38 \pm 0.03^{\mathrm{b}}$ & ND & ND & MS, RI \\
\hline 7 & 21.60 & $\begin{array}{l}\text { Dodecyl aldehyde } \\
\text { Alcohols }\end{array}$ & 1409 & $\mathrm{C}_{12} \mathrm{H}_{24} \mathrm{O}$ & 184.18 & $112-54-9$ & $0.66 \pm 0.09 \mathrm{a}$ & ND & ND & ND & ND & ND & RI \\
\hline 8 & 7.21 & 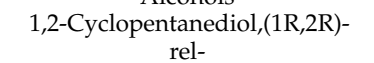 & - & $\mathrm{C}_{5} \mathrm{H}_{10} \mathrm{O}_{2}$ & 102.07 & 5057-99-8 & $2.29 \pm 0.43^{\mathrm{a}}$ & ND & ND & ND & ND & ND & MS, RI \\
\hline 9 & 7.25 & 1,3-Cyclopentanediol, trans & - & $\mathrm{C}_{5} \mathrm{H}_{10} \mathrm{O}_{2}$ & 102.07 & $16326-98-0$ & ND & $2.14 \pm 0.40^{\mathrm{a}}$ & ND & ND & ND & ND & MS, RI \\
\hline 10 & 13.41 & 1-Pentanol & 822 & $\mathrm{C}_{5} \mathrm{H}_{12} \mathrm{O}$ & 104.07 & $110-66-7$ & ND & $7.32 \pm 0.58^{\mathrm{a}}$ & ND & ND & ND & $5.63 \pm 0.30^{b}$ & MS, RI \\
\hline 11 & 18.08 & 1-Hexanol & 868 & $\mathrm{C}_{6} \mathrm{H}_{14} \mathrm{O}$ & 102.10 & $111-27-3$ & $3.46 \pm 0.46^{\mathrm{a}}$ & $2.23 \pm 0.33^{b}$ & ND & ND & ND & ND & MS, RI \\
\hline 12 & 21.71 & 1-Heptanol & 970 & $\mathrm{C}_{7} \mathrm{H}_{16} \mathrm{O}$ & 116.12 & $111-70-6$ & $1.03 \pm 0.10^{\mathrm{a}}$ & ND & ND & ND & ND & ND & MS, RI \\
\hline 13 & 23.21 & 6-Methyl-5-hepten-2-ol & 994 & $\mathrm{C}_{8} \mathrm{H}_{16} \mathrm{O}$ & 128.12 & $1569-60-4$ & ND & ND & $0.87 \pm 0.15^{b}$ & ND & ND & $1.54 \pm 0.18^{\mathrm{a}}$ & MS, RI \\
\hline 14 & 23.99 & 2,3-Butanediol & - & $\mathrm{C}_{4} \mathrm{H}_{10} \mathrm{O}_{2}$ & 90.07 & 513-85-9 & ND & $1.85 \pm 0.09^{\mathrm{a}}$ & $\mathrm{ND}$ & ND & ND & ND & RI \\
\hline 15 & 25.43 & 1,2,3-Butanetriol & - & $\mathrm{C}_{4} \mathrm{H}_{10} \mathrm{O}_{3}$ & 106.06 & $4435-50-1$ & $1.62 \pm 0.21^{\mathrm{b}}$ & $2.55 \pm 0.25$ a & ND & $1.37 \pm 0.18^{\mathrm{b}}$ & ND & ND & MS \\
\hline 16 & 27.60 & $\begin{array}{c}\text { Furfuryl alcohol } \\
(1 \alpha, 2 \beta, 5 \alpha) 2 \text {-Methyl-5-(1- }\end{array}$ & 859 & $\mathrm{C}_{5} \mathrm{H}_{6} \mathrm{O}_{2}$ & 98.04 & $98-00-0$ & $\begin{array}{l}1.02 \\
\mathrm{ND}\end{array}$ & ND & ND & $\mathrm{ND}$ & ND & $1.04 \pm 0.40^{\mathrm{a}}$ & MS, RI \\
\hline 17 & 28.10 & $\begin{array}{l}\text { methylvinyl) } \\
\text { cyclohexanol }\end{array}$ & 1192 & $\mathrm{C}_{10} \mathrm{H}_{18} \mathrm{O}$ & 154.14 & $38049-26-2$ & ND & ND & ND & ND & $2.92 \pm 0.10^{a}$ & ND & MS, RI \\
\hline 18 & 29.84 & $\begin{array}{l}\text { Alpha,alpha-dimethyl-benzyl } \\
\text { alcohol }\end{array}$ & 1090 & $\mathrm{C}_{9} \mathrm{H}_{12} \mathrm{O}$ & 136.09 & $617-94-7$ & ND & $0.74 \pm 0.03^{\mathrm{b}}$ & ND & $0.82 \pm 0.03^{\mathrm{b}}$ & $2.64 \pm 0.18^{\mathrm{a}}$ & $0.65 \pm 0.04^{\mathrm{b}}$ & MS, RI \\
\hline 20 & 32.19 & 2-Hexadecanol & 1702 & $\mathrm{C}_{16} \mathrm{H}_{34} \mathrm{O}$ & 242.26 & 14852-31-4 & ND & ND & $3.93 \pm 0.50^{\mathrm{a}}$ & ND & ND & ND & RI \\
\hline 21 & 34.19 & 1-Dodecanol & 1473 & $\mathrm{C}_{12} \mathrm{H}_{26} \mathrm{O}$ & 186.20 & $112-53-8$ & ND & ND & $2.10 \pm 0.41^{\mathrm{c}}$ & $3.17 \pm 0.21^{\mathrm{b}}$ & $5.74 \pm 0.12^{\mathrm{a}}$ & $1.50 \pm 0.14^{\mathrm{d}}$ & \\
\hline 22 & 34.47 & $\begin{array}{l}\text { Bicyclo[3.1.1]hept-3-en-2- } \\
\text { ol,4,6,6-trimethyl- } \\
\text { Ketones }\end{array}$ & 1140 & $\mathrm{C}_{10} \mathrm{H}_{16} \mathrm{O}$ & 152.12 & $473-67-6$ & ND & ND & $0.78 \pm 0.21^{\mathrm{a}}$ & ND & ND & ND & RI \\
\hline 23 & 6.38 & 2,3-Pentanedione & 698 & $\mathrm{C}_{5} \mathrm{H}_{8} \mathrm{O}_{2}$ & 100.05 & $600-14-6$ & ND & $1.95 \pm 0.25^{\mathrm{a}}$ & ND & ND & ND & ND & MS, RI \\
\hline 24 & 10.40 & 2-Heptanone & 891 & $\mathrm{C}_{7} \mathrm{H}_{14} \mathrm{O}$ & 114.10 & $110-43-0$ & $1.58 \pm 0.62^{\mathrm{a}}$ & $4.35 \pm 0.52^{\mathrm{a}}$ & $2.75 \pm 0.14^{\mathrm{b}}$ & $2.92 \pm 0.41^{\mathrm{b}}$ & ND & $4.73 \pm 0.33^{a}$ & MS, RI \\
\hline 25 & 10.54 & Heptaldehyde & 901 & $\mathrm{C}_{7} \mathrm{H}_{14} \mathrm{O}$ & 114.10 & $111-71-7$ & ND & ND & ND & $1.01 \pm 0.14^{\mathrm{a}}$ & ND & ND & MS, RI \\
\hline 26 & 19.19 & 2-Nonanone & 1092 & $\mathrm{C}_{9} \mathrm{H}_{18} \mathrm{O}$ & 142.14 & $821-55-6$ & ND & $3.74 \pm 0.22^{\mathrm{a}}$ & $2.82 \pm 0.14^{b}$ & $3.45 \pm 0.78 \mathrm{ab}$ & ND & $3.63 \pm 0.26^{a b}$ & MS, RI \\
\hline 27 & 22.70 & 2-Tridecanone & 1497 & $\mathrm{C}_{13} \mathrm{H}_{26} \mathrm{O}$ & 198.20 & $593-08-8$ & ND & ND & ND & $3.70 \pm 0.11^{\mathrm{a}}$ & ND & $1.59 \pm 0.14^{\mathrm{b}}$ & MS, RI \\
\hline 28 & 22.82 & $\begin{array}{l}\text { 2-Decanone } \\
\text { Esters }\end{array}$ & 1193 & $\mathrm{C}_{10} \mathrm{H}_{20} \mathrm{O}$ & 156.15 & 693-54-9 & $1.05 \pm 0.21^{\mathrm{d}}$ & $1.36 \pm 0.01^{\mathrm{d}}$ & $2.18 \pm 0.12^{c}$ & $4.37 \pm 0.32^{a}$ & ND & $2.64 \pm 0.12^{b}$ & MS, RI \\
\hline 29 & 5.67 & Arachic acid benzyl ester & 3003 & $\mathrm{C}_{27} \mathrm{H}_{46} \mathrm{O}_{2}$ & 402.35 & 77509-04-7 & ND & ND & ND & ND & ND & $4.23 \pm 0.16^{\mathrm{a}}$ & MS \\
\hline 30 & 12.50 & Ethyl caproate & 1000 & $\mathrm{C}_{8} \mathrm{H}_{16} \mathrm{O}_{2}$ & 144.12 & $123-66-0$ & $15.31 \pm 0.28^{\mathrm{a}}$ & $15.53 \pm 1.77^{\mathrm{a}}$ & $2.73 \pm 0.09^{c}$ & $2.08 \pm 0.18^{c}$ & $8.56 \pm 0.96^{b}$ & $14.38 \pm 0.31^{a}$ & MS, RI \\
\hline 31 & 17.06 & Ethyl heptanoate & 1097 & $\mathrm{C}_{9} \mathrm{H}_{18} \mathrm{O}_{2}$ & 158.14 & $106-30-9$ & $2.12 \pm 0.11^{\mathrm{a}}$ & ND & ND & ND & ND & ND & MS, RI \\
\hline 32 & 20.87 & Ethyl caprylate & 1196 & $\mathrm{C}_{10} \mathrm{H}_{20} \mathrm{O}_{2}$ & 172.14 & $106-32-1$ & $8.23 \pm 1.59^{\mathrm{a}}$ & $1.41 \pm 0.07^{b}$ & $1.94 \pm 0.19^{b}$ & $0.97 \pm 0.04^{\mathrm{b}}$ & ND & $1.43 \pm 0.21^{b}$ & MS, RI \\
\hline 33 & 21.70 & Hexyl formate & 1039 & $\mathrm{C}_{8} \mathrm{H}_{16} \mathrm{O}_{2}$ & 144.12 & $112-23-2$ & ND & $1.30 \pm 0.04 \mathrm{a}$ & ND & ND & ND & ND & RI \\
\hline 34 & 23.99 & Ethyl nonanoate & 1296 & $\mathrm{C}_{11} \mathrm{H}_{22} \mathrm{O}_{2}$ & 186.16 & $123-29-5$ & $6.35 \pm 0.25^{\mathrm{a}}$ & ND & ND & ND & ND & ND & MS, RI \\
\hline 35 & 26.56 & $\gamma$-Butyrolactone & 915 & $\mathrm{C}_{4} \mathrm{H}_{6} \mathrm{O}_{2}$ & 86.04 & $96-48-0$ & ND & $1.94 \pm 0.11^{c}$ & $2.23 \pm 0.43^{b c}$ & $2.79 \pm 0.25 \mathrm{ab}$ & ND & $3.33 \pm 0.34^{\mathrm{a}}$ & MS, RI \\
\hline
\end{tabular}


Table 1. Cont.

\begin{tabular}{|c|c|c|c|c|c|c|c|c|c|c|c|c|c|}
\hline \multirow{2}{*}{ Count } & \multirow{2}{*}{ RT } & \multirow{2}{*}{ Compounds } & \multirow{2}{*}{ RI } & \multirow{2}{*}{ Formula } & \multirow{2}{*}{$\begin{array}{c}\text { Molecular } \\
\text { Ion Mass } \\
(\mathbf{M}+)\end{array}$} & \multirow{2}{*}{ CAS\# } & \multicolumn{6}{|c|}{ Relative Content/(\%) } & \multirow{2}{*}{$\begin{array}{l}\text { Qualitative } \\
\text { Method }\end{array}$} \\
\hline & & & & & & & $0 \mathrm{~min}$ & $4 \mathrm{~min}$ & $8 \mathrm{~min}$ & $12 \mathrm{~min}$ & $16 \mathrm{~min}$ & $20 \mathrm{~min}$ & \\
\hline 36 & 29.04 & Benzyl acetate & 1164 & $\mathrm{C}_{9} \mathrm{H}_{10} \mathrm{O}_{2}$ & 150.07 & $140-11-4$ & ND & ND & ND & ND & $2.71 \pm 0.10^{\mathrm{a}}$ & ND & RI \\
\hline 37 & 29.95 & Arachic acid benzyl ester & 1298 & $\mathrm{C}_{12} \mathrm{H}_{16} \mathrm{O}_{2}$ & 192.12 & $151-05-3$ & ND & ND & ND & ND & $1.45 \pm 0.24 \mathrm{a}$ & ND & MS, RI \\
\hline 38 & 35.45 & $\gamma$-Undecanolactone & 1576 & $\mathrm{C}_{11} \mathrm{H}_{20} \mathrm{O}_{2}$ & 184.15 & $104-67-6$ & $0.68 \pm 0.05^{b}$ & $0.52 \pm 0.09^{b}$ & $1.47 \pm 0.09^{\mathrm{a}}$ & $0.71 \pm 0.15^{b}$ & ND & $0.71 \pm 0.17^{\mathrm{b}}$ & MS, RI \\
\hline 40 & 40.96 & Dimethyl phthalate & 1454 & $\mathrm{C}_{10} \mathrm{H}_{10} \mathrm{O}_{4}$ & 194.06 & $131-11-3$ & $1.78 \pm 1.56^{\mathrm{d}}$ & $1.16 \pm 0.14^{\mathrm{f}}$ & $8.83 \pm 0.24^{a}$ & $3.54 \pm 0.62^{\mathrm{c}}$ & $4.61 \pm 0.13^{\mathrm{b}}$ & $1.68 \pm 0.15 \mathrm{df}$ & MS, RI \\
\hline 41 & 43.36 & Ethyl oleate & 2173 & $\mathrm{C}_{20} \mathrm{H}_{38} \mathrm{O}_{2}$ & 310.29 & $111-62-6$ & $1.45 \pm 0.0^{\mathrm{c}}$ & $0.60 \pm 0.19^{\mathrm{d}}$ & $4.80 \pm 0.10^{\mathrm{a}}$ & $2.35 \pm 0.62^{b}$ & ND & ND & MS, RI \\
\hline 42 & 43.96 & Ethyl linoleate & 2162 & $\mathrm{C}_{20} \mathrm{H}_{36} \mathrm{O}_{2}$ & 308.27 & $544-35-4$ & ND & ND & $1.53 \pm 0.19^{\mathrm{a}}$ & ND & ND & ND & MS \\
\hline 43 & 44.22 & $\begin{array}{l}\text { Diisobutyl phthalate } \\
\text { Acids }\end{array}$ & 2317 & $\mathrm{C}_{16} \mathrm{H}_{22} \mathrm{O}_{4}$ & 334.21 & $84-69-5$ & ND & ND & $4.57 \pm 0.28^{a}$ & ND & ND & ND & MS, RI \\
\hline 44 & 22.09 & $\begin{array}{c}\text { Malonic acid } \\
\text { 3-Methyl-3,7-dimethyl-2,6- }\end{array}$ & - & $\mathrm{C}_{3} \mathrm{H}_{4} \mathrm{O}_{4}$ & 104.01 & $141-82-2$ & $1.61 \pm 0.12^{b}$ & ND & ND & ND & $6.35 \pm 0.83^{a}$ & ND & RI \\
\hline 45 & 25.65 & $\begin{array}{c}\text { octadienyl ester,(E)-Butanoic } \\
\text { acid }\end{array}$ & 1606 & $\mathrm{C}_{15} \mathrm{H}_{26} \mathrm{O}_{2}$ & 238.19 & $109-20-6$ & ND & ND & $1.63 \pm 0.22^{\mathrm{a}}$ & & ND & ND & RI \\
\hline 46 & 27.94 & 2-Propylmalonic acid & - & $\mathrm{C}_{6} \mathrm{H}_{10} \mathrm{O}_{4}$ & 146.06 & $616-62-6$ & $1.48 \pm 0.28^{a}$ & ND & ND & ND & ND & ND & MS \\
\hline 47 & 29.54 & Valeric acid & 904 & $\mathrm{C}_{5} \mathrm{H}_{10} \mathrm{O}_{2}$ & 102.07 & $109-52-4$ & $2.37 \pm 0.25^{\mathrm{a}}$ & $0.75 \pm 0.13^{b}$ & ND & ND & ND & ND & MS, RI \\
\hline 48 & 31.92 & Hexanoic acid & 990 & $\mathrm{C}_{6} \mathrm{H}_{12} \mathrm{O}_{2}$ & 116.08 & $142-62-1$ & $\mathrm{ND}$ & ND & $1.89 \pm 0.65^{b}$ & $1.40 \pm 0.18^{b}$ & ND & $3.23 \pm 0.27^{a}$ & MS, RI \\
\hline 49 & 36.37 & Octanoic acid & 1180 & $\mathrm{C}_{8} \mathrm{H}_{16} \mathrm{O}_{2}$ & 144.12 & $124-07-2$ & $1.58 \pm 0.05^{\mathrm{a}}$ & ND & $1.33 \pm 0.03^{b}$ & ND & ND & ND & MS, RI \\
\hline 50 & 38.75 & $\begin{array}{l}\text { Nonanoic acid } \\
\text { Olefins }\end{array}$ & 1273 & $\mathrm{C}_{9} \mathrm{H}_{18} \mathrm{O}_{2}$ & 158.13 & $112-05-0$ & $0.790 .23^{\mathrm{a}}$ & ND & $0.99 \pm 0.05^{\mathrm{a}}$ & ND & ND & ND & MS, RI \\
\hline 51 & 10.77 & (-)-Limonene & 1031 & $\mathrm{C}_{10} \mathrm{H}_{16}$ & 136.13 & $5989-54-8$ & ND & ND & $1.17 \pm 0.24^{b}$ & $5.93 \pm 0.74^{\mathrm{a}}$ & ND & ND & MS, RI \\
\hline 52 & 13.38 & $\begin{array}{l}\text { Phenylethylene } \\
\text { Alkanes }\end{array}$ & 893 & $\mathrm{C}_{8} \mathrm{H}_{8}$ & 104.06 & $100-42-5$ & $8.31 \pm 0.77^{\mathrm{a}}$ & ND & $5.46 \pm 0.10^{\mathrm{b}}$ & $5.46 \pm 0.25^{b}$ & $8.95 \pm 0.93^{\mathrm{a}}$ & ND & MS, RI \\
\hline 53 & 18.10 & Decylamine & 1255 & $\mathrm{C}_{10} \mathrm{H}_{23} \mathrm{~N}$ & 157.18 & $2016-57-1$ & ND & ND & ND & ND & ND & $1.81 \pm 0.18^{\mathrm{a}}$ & RI \\
\hline 55 & 13.73 & 2-Methylpyrazine & 831 & $\mathrm{C}_{5} \mathrm{H}_{6} \mathrm{~N}_{2}$ & 94.05 & $109-08-0$ & ND & $2.85 \pm 0.33^{b}$ & $1.18 \pm 0.05^{c}$ & $2.48 \pm 0.12^{b}$ & ND & $4.49 \pm 0.39^{\mathrm{a}}$ & MS, RI \\
\hline 56 & 16.29 & 2,5-Dimethyl pyrazine & 917 & $\mathrm{C}_{6} \mathrm{H}_{8} \mathrm{~N}_{2}$ & 108.07 & $123-32-0$ & ND & $7.93 \pm 0.90^{a}$ & $2.39 \pm 0.54^{b}$ & $3.36 \pm 0.09^{b}$ & ND & $6.97 \pm 0.54^{\mathrm{a}}$ & MS, RI \\
\hline 57 & 16.92 & Pyrazine,2-methyl-3-(2- & 1134 & $\mathrm{C}_{9} \mathrm{H}_{14} \mathrm{~N}_{2}$ & 150.12 & $13925-06-9$ & ND & $0.69 \pm 0.09^{b}$ & $0.65 \pm 0.04^{\mathrm{b}}$ & ND & ND & $1.08 \pm 0.21^{\mathrm{a}}$ & MS, RI \\
\hline 58 & 19.56 & 2,3,5-Trimethylpyrazine & 1004 & $\mathrm{C}_{7} \mathrm{H}_{10} \mathrm{~N}_{2}$ & 122.08 & $14667-55-1$ & ND & $0.74 \pm 0.07^{b}$ & ND & ND & ND & $0.95 \pm 0.07^{a}$ & MS, RI \\
\hline 59 & 21.02 & $\begin{array}{c}\text { Pyrazine,2-ethyl-3,5-dimethyl } \\
\text { Other }\end{array}$ & 1084 & $\mathrm{C}_{8} \mathrm{H}_{12} \mathrm{~N}_{2}$ & 136.10 & $13925-07-0$ & ND & $2.20 \pm 0.14^{b}$ & $1.27 \pm 0.12^{\mathrm{c}}$ & $1.41 \pm 0.07^{c}$ & $3.10 \pm 0.52^{\mathrm{a}}$ & $3.08 \pm 0.20^{\mathrm{a}}$ & MS, RI \\
\hline 60 & 5.63 & Toluene & 763 & $\mathrm{C}_{7} \mathrm{H}_{8}$ & 92.06 & $108-88-3$ & ND & ND & $2.44 \pm 1.22^{\mathrm{b}}$ & $4.29 \pm 0.36^{\mathrm{a}}$ & $8.58 \pm 1.58^{b}$ & ND & RI \\
\hline 61 & 8.28 & 1,2-Xylene & 887 & $\mathrm{C}_{8} \mathrm{H}_{10}$ & 106.08 & $95-47-6$ & ND & ND & $\mathrm{ND}$ & ND & $9.21 \pm 0.55^{\mathrm{a}}$ & ND & MS \\
\hline 62 & 8.34 & (+)-Phenaminum & 1141 & $\mathrm{C}_{9} \mathrm{H}_{13} \mathrm{~N}$ & 135.10 & $51-64-9$ & ND & ND & ND & ND & ND & $1.30 \pm 0.16^{\mathrm{a}}$ & MS \\
\hline 63 & 8.74 & 1,4-Xylene & 865 & $\mathrm{C}_{8} \mathrm{H}_{10}$ & 106.08 & $106-42-3$ & $5.21 \pm 0.49^{b}$ & ND & ND & $1.22 \pm 0.08^{c}$ & ND & ND & MS, RI \\
\hline 64 & 12.40 & 2-Pentylfuran & 993 & $\mathrm{C}_{9} \mathrm{H}_{14} \mathrm{O}$ & 138.10 & $3777-69-3$ & $0.61 \pm 0.08^{c}$ & ND & $1.08 \pm 0.04^{b}$ & $1.39 \pm 0.06^{\mathrm{a}}$ & ND & ND & MS, RI \\
\hline 65 & 30.52 & Butyldiglycol & 1192 & $\mathrm{C}_{8} \mathrm{H}_{18} \mathrm{O}_{3}$ & 162.13 & $112-34-5$ & ND & $1.71 \pm 0.04^{b}$ & $1.48 \pm 0.81^{b}$ & $2.21 \pm 0.16^{b}$ & $6.46 \pm 0.32^{\mathrm{a}}$ & $1.44 \pm 0.14^{b}$ & MS, RI \\
\hline 66 & 35.27 & 2-Acetyl pyrrole & 1064 & $\mathrm{C}_{6} \mathrm{H}_{7} \mathrm{NO}$ & 109.05 & $1072-83-9$ & ND & ND & ND & $0.50 \pm 0.02^{\mathrm{a}}$ & ND & $0.75 \pm 0.23^{\mathrm{a}}$ & RI \\
\hline 67 & 35.73 & $\begin{array}{l}\text { 2H-Pyran,tetrahydro } \\
\text {-2-(2-propyn-1-yloxy)- }\end{array}$ & 976 & $\mathrm{C}_{8} \mathrm{H}_{12} \mathrm{O}_{2}$ & 140.08 & 6089-04-9 & ND & $\mathrm{ND}$ & $2.66 \pm 0.15^{\mathrm{a}}$ & ND & ND & $\mathrm{ND}$ & MS, RI \\
\hline 68 & 39.27 & 4-Hydroxy-3-methoxystyrene & 1317 & $\mathrm{C}_{9} \mathrm{H}_{10} \mathrm{O}_{2}$ & 150.07 & 7786-61-0 & ND & ND & $3.21 \pm 0.22^{\mathrm{a}}$ & ND & ND & $1.53 \pm 0.22^{b}$ & MS, RI \\
\hline
\end{tabular}

(hetered. Different lowercase letters in the same row indicate that there was a significant difference $(p<0.05)$. MS: Identification based on the NIST mass spectrometry database. 
Aldehydes are mainly produced by lipid oxidation, decomposition, and Strecker degradation of amino acid, and their odor threshold is low $[23,24]$. They account for a large proportion of the VOCs of defatted tiger nut flour and are the main compounds that affect its odor. Among these, 3-methylbutyraldehyde, valeraldehyde, and hexanal play an essential role in the odor of defatted tiger nut flour. As the baking time increased, 3-methylbutanal was produced by the degradation of leucine, which indicates that cocoa, sweet and baked aromas increased [25]. The reduction in hexanal indicates that the aromas of soybean, malt and grass were reduced; these are oxidation products of unsaturated fatty acids such as linoleic acid and oleic acid [26].

Alcohols, mainly derived from the thermal oxidation of lipids and degradation of carbohydrates [27], with vegetal and aromatic odors, had a higher odor threshold and less impact on the aroma of the defatted tiger nut flour than aldehydes and ketones [28]. Baking increased the types of alcohols; among them, hexanol had a grassy aroma and disappeared after $4 \mathrm{~min}$ of baking. Defatted tiger nut flour baked for $8 \mathrm{~min}$ produced 1-dodecanol and bicyclo [3.1.1] hept-3-en-2-ol,4,6,6-trimethyl-, which increased violet and verbena aromas. These added new VOCs to the defatted tiger nut flour and improved the richness of the aroma compounds.

Ketones, mainly from the thermal degradation of amino acids or thermal oxidation of polyunsaturated fatty acids [29], have a high odor threshold and impacted odor only slightly [30]. 2-Nonanone and 2-tridecone were formed after baking defatted tiger nut flour, adding fruity and coconut aromas. Upon baking, the relative content of 2-heptanone and 2-decanone increased, indicating that cheese and fruit aromas increased; 2-heptanone is produced by amino acid decomposition [26].

Esters are typically generated by the dehydration of hydroxy fatty acids [31], with a low odor threshold. They have creamy and fruity aromas and are essential components of an odor [32]. Baking defatted tiger nut flour generated $\gamma$-undecanolactone, and its relative content gradually increased, enhancing peanut and nutty aromas. $\gamma$-Undecanolide (peach aldehyde) was the aroma of the raw material itself, and its relative content rose after baking for $8 \mathrm{~min}$, with coconut and peach-like aromas [33]. $\gamma$-Butyrolactone is formed after roasting and has a nutty aroma, resulting from the esterification of hydroxy fatty acids or the oxidation of unsaturated aldehydes.

As one of the critical products of the Maillard reaction, pyrazines are formed by Strecker degradation of leucine, isoleucine, and glycine [34], and have strong sensory characteristics. They typically have baked aromas such as baked hazelnuts, baked barley, and baked corn [35]. Defatted tiger nut flour generated 2-methylpyrazine, 2,5-dimethyl pyrazine, pyrazine,2-methyl-3-(2-methylpropyl)-2,3,5-Trimethylpyrazine, and pyrazine,2ethyl-3,5- dimethyl- after baking, with typical baking aromas such as fried peanuts, nut, roasted potato, and coffee [36,37]. Furans are oxygenated heterocyclic compounds generated by the Maillard reaction and caramelization, mainly from the cyclization and dehydration of Amadori compounds [25,38], which mainly have caramel and nutty aromas. After baking, the relative content of 2-pentylfuran increased significantly, and buttery, mung bean, floral, and fruity aromas gradually became stronger in the defatted tiger nut flour [39].

Acids are produced by the further oxidation of aldehydes; they have a high odor threshold and have little effect on the odor [40]. They have cheesy, fruity, and sour aromas [41]. When defatted tiger nut flour was baked for $8 \mathrm{~min}$, the relative content of hexanoic acid, octanoic acid, and nonanoic acid increased, indicating increased coconut and cheese aromas. Alkanes have a higher odor threshold and weaker effect on the odor. Olefins generally have a lower odor threshold and present floral and fruity aromas [42]. The higher relative content of (-)-limonene in defatted tiger nut flour at $8 \mathrm{~min}$ of baking increased the lemon aroma [43], resulting in richer VOCs.

In summary, reasonable baking conditions can improve the richness of VOCs of defatted tiger nut flour and achieve the purpose of improving aroma. When baked for $8 \mathrm{~min}$, the relative content of valeraldehyde, hexanal, and 1-hexanol in defatted tiger nut 
flour decreased, and thus, grassy odors decreased. Meanwhile, 3-methylbutyraldehyde, 2-heptanone, 2-nonanone, $\gamma$-undecanolide, (-)-limonene and other fruit aroma compounds as well as baking aroma compounds, such as pyrazine, increased. However, excessive baking will destroy the prominent odor and produce a burnt odor and harmful substances. When the baking time exceeded $12 \mathrm{~min}$, pyrazine significantly increased, and the samples had caramel and burnt aromas and bitterness.

As shown in Figure 1, the defatted tiger nut flour primarily contained more aldehydes, followed by esters, alcohols and ketones. Baking for $8 \mathrm{~min}$ produced the most abundant VOCs, with 39 types in total, 11 more than the VOCs in unbaked defatted tiger nut flour. There were 15 aldehydes and 13 esters, which were the main VOCs. The baked defatted tiger nut flour produced pyrazines, adding caramel and baked nut aromas. Upon baking for $20 \mathrm{~min}$, the relative content and types of pyrazine were higher, and the content of aldehydes was lower, indicating that the odor had changed too much and that the original and baking aromas had declined while the burnt odor was higher.

A

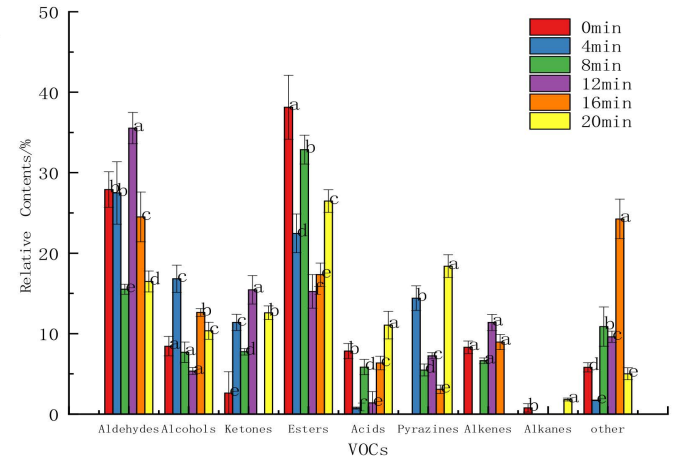

B

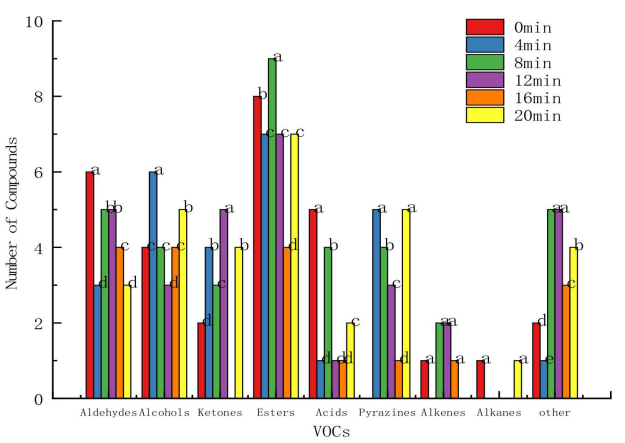

Figure 1. Relative content (A) and number (B) of VOCs in defatted tiger nut flour. Different lowercase letters in the same classification indicate that there was a significant difference $(p<0.05)$.

\subsection{Heat Map Analysis of Volatile Flavor Compounds in Defatted Tiger Nut Flour}

In the heat map, the difference between the content of various VOCs and the average content is indicated by different shades of color, providing a more visual indication of the differences between the samples [44]. The relative content of each volatile flavor compound is marked with a different color in the heat map. The darker the red, the greater the relative content, and the darker the blue, the less the relative content [45]. As can be seen from Figure 2, when the defatted tiger nut flour was baked for $8 \mathrm{~min}$, the relative contents of 2-pentylfuran (buttery and floral), caprylic acid (cheese), nonanoic acid (fatty and coconut), $\gamma$-undecanolactone (peach, coconut, and milk), and bicyclo[3.1.1]hept-3-en-2ol,4,6,6-trimethyl-(verbena) were significantly higher. When baked for $8 \mathrm{~min}$, the defatted tiger nut flour had more positive VOCs and the relative content was higher, indicating that the richness of its aroma was greater. When baked for 16 and $20 \mathrm{~min}$, the VOCs of defatted tiger nut flour were mainly composed of pyrazines, with coffee and burnt aromas. At this point, the richness of the aromas decreased significantly and their sensory quality was low. 


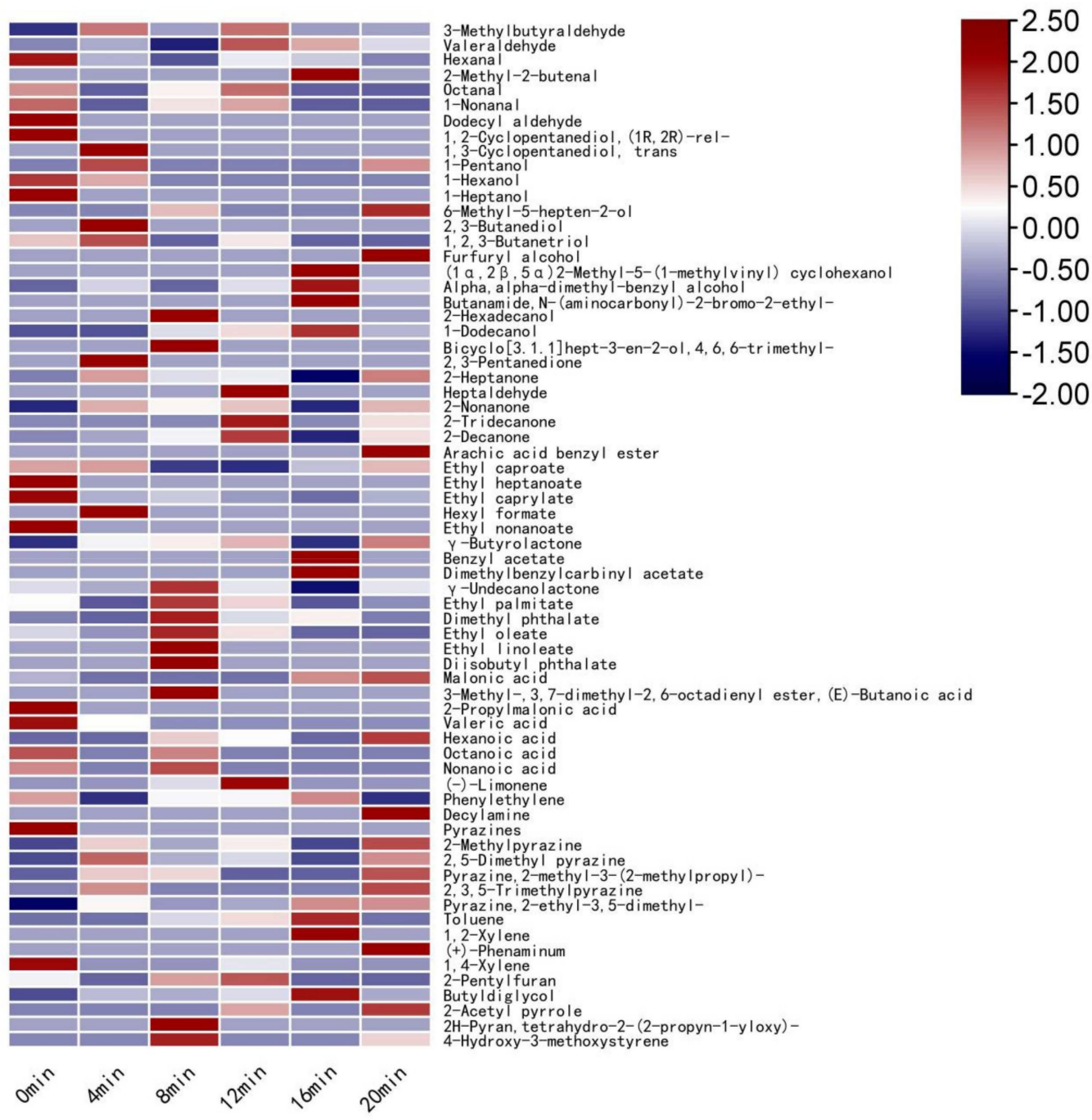

Figure 2. Heat map of volatile compounds in defatted tiger nut flour.

\subsection{Relative Odor Activity Value (ROAV)}

The sample's odor was determined by both the relative content of each VOC and its threshold value; when the content was certain and the threshold value was smaller, the greater the contribution to odor. The ROAV method was used to determine the contribution of each volatile compound to the main odor. The greater the ROAV value, the greater the contribution to the main odor, and the compounds with ROAV $>1$ were key volatile compounds.

It can be seen from Table 2 and Figure 3. Without baking, defatted tiger nut flour's odor was mainly attributable to 3-methylbutanal, hexanal and 2-heptanone with light fruit, malt, almond, grassy, and other original aromas. When baked for $8 \mathrm{~min}$, its key volatile compound types were 3-methylbutanal, 1-hexanal, octanal, 1-nonanal, 2,5 dimethyl pyrazine, and pyrazine,2-ethyl-3,5-dimethyl-, significantly contributing to the odor. Bicyclo[3.1.1]hept3-en-2-ol,4,6,6-trimethyl-, 2-heptanone, octanoic acid, (-)-limonene, and other compounds contributed less, indicating that baking for $8 \mathrm{~min}$ both retained the original aroma of the defatted tiger nut flour and added fruity, sweet, fried peanut and baking aromas. When baked for 16 and $20 \mathrm{~min}$, the ROAV of 2-ethyl-3,5-dimethyl pyrazine reached 43.18 and 41.62, respectively; thus, the fried peanut and coffee aromas were too heavy, and the samples had a strong burnt odor, which greatly reduced the quality. 
Table 2. ROAV of defatted tiger nut flour.

\begin{tabular}{|c|c|c|c|c|c|c|c|c|c|}
\hline \multirow{2}{*}{ Count } & \multirow{2}{*}{ Compounds } & \multirow{2}{*}{$\begin{array}{c}\text { Aroma } \\
\text { Characteristics }\end{array}$} & \multirow{2}{*}{$\begin{array}{l}\text { Threshold } \\
\mu \mathrm{g} / \mathrm{kg}\end{array}$} & \multicolumn{6}{|c|}{ ROAV } \\
\hline & & & & $0 \mathrm{~min}$ & $4 \mathrm{~min}$ & $8 \mathrm{~min}$ & $12 \mathrm{~min}$ & $16 \mathrm{~min}$ & $20 \mathrm{~min}$ \\
\hline 1 & 3-Methylbutyraldehyde & $\begin{array}{c}\text { Light Fruit, Sweet, } \\
\text { Malt }\end{array}$ & 1.00 & 66.14 & 100 & 100 & 100 & 100 & 100 \\
\hline 2 & Valeraldehyde & $\begin{array}{l}\text { Almond, Grass, } \\
\text { Malt, Oil }\end{array}$ & 12.00 & 5.74 & 1.49 & 2.12 & 2.54 & 5.28 & 3.92 \\
\hline 3 & Hexanal & Grass, Fat & 4.50 & 100 & 9.41 & 12.15 & 11.77 & 25.19 & 16.82 \\
\hline 4 & 2-Methyl-2-butenal & & 458.90 & - & - & - & - & 0.14 & - \\
\hline 5 & Octanal & Fat, Soap & 0.70 & 74.51 & - & 26.22 & 19.63 & - & - \\
\hline 6 & 1-1-Nonanal & Rose, Citrus, Fat & 1.00 & 42.68 & - & 14.11 & 7.97 & - & - \\
\hline 7 & 1-Pentanol & & 15.00 & - & 2.85 & - & - & - & 5.18 \\
\hline 8 & 1-Hexanol & $\begin{array}{l}\text { Potato, Grass, } \\
\text { Celery }\end{array}$ & 2.50 & 34.54 & 5.20 & - & - & - & - \\
\hline 9 & 1-Heptanol & & 330.00 & 0.08 & - & - & - & - & - \\
\hline 10 & $\begin{array}{l}\text { Bicyclo[3.1.1]hept-3-en-2- } \\
\text { ol,4,6,6-trimethyl- }\end{array}$ & Verbena & 4.00 & - & - & 2.67 & - & - & - \\
\hline 11 & 2-Heptanone & $\begin{array}{c}\text { Cheese, Fruit, Grass } \\
\text { Meat }\end{array}$ & 14.00 & 2.82 & 1.81 & 2.69 & 1.20 & - & 4.57 \\
\hline 12 & 2-Nonanone & Fruity, Soap & 100.00 & - & 0.22 & 0.39 & 0.20 & - & 0.49 \\
\hline 13 & 2-Decanone & & 7.94 & 3.3 & 1.00 & 3.76 & 3.18 & - & 4.49 \\
\hline 14 & Ethyl heptanoate & Pineapple & 1.90 & 27.85 & - & - & - & - & - \\
\hline 15 & Ethyl caprylate & $\begin{array}{l}\text { Pear, Flower } \\
\text { and Pineapple }\end{array}$ & 12.87 & 15.96 & 0.64 & 2.06 & 0.44 & - & 1.50 \\
\hline 16 & Octanoic acid & Cheese, Oil, Sweat & 5.10 & 7.73 & - & 3.57 & - & - & - \\
\hline 17 & (-)-Limonene & Lemon & 10.00 & - & - & 1.60 & 3.42 & - & - \\
\hline 18 & 2-Methylpyrazine & $\begin{array}{l}\text { Roasted peanut, } \\
\text { Nut }\end{array}$ & 60.00 & - & 0.28 & 0.27 & 0.24 & - & 1.01 \\
\hline 19 & 2,5-Dimethyl pyrazine & $\begin{array}{l}\text { Fried peanut, } \\
\text { Chocolate }\end{array}$ & 1.80 & - & 25.69 & 18.19 & 10.78 & - & 52.33 \\
\hline 20 & $\begin{array}{l}\text { Pyrazine,2-methyl-3-(2- } \\
\text { methylpropyl)- }\end{array}$ & Celery & 35.00 & - & 0.28 & 0.27 & 0.24 & - & 1.01 \\
\hline 21 & Pyrazine,2-ethyl-3,5-dimethyl- & $\begin{array}{l}\text { Fried peanut, } \\
\text { Coffee }\end{array}$ & 1.00 & - & 12.83 & 17.40 & 8.14 & 43.18 & 41.62 \\
\hline 22 & 2-Pentylfurana & Butter, Flower, Fruit & 6.00 & 2.54 & - & 2.47 & 1.34 & - & - \\
\hline
\end{tabular}

Aroma characteristics were retrieved from Flavornet. ROAV $>0.1$ are presented at least, $0.1<\mathrm{ROAV}<1$ : the compound contributed little to the odor, ROAV $>1$ : the compound is a key volatile compound. "-": Not identified, or $\mathrm{ROAV}<0.1$

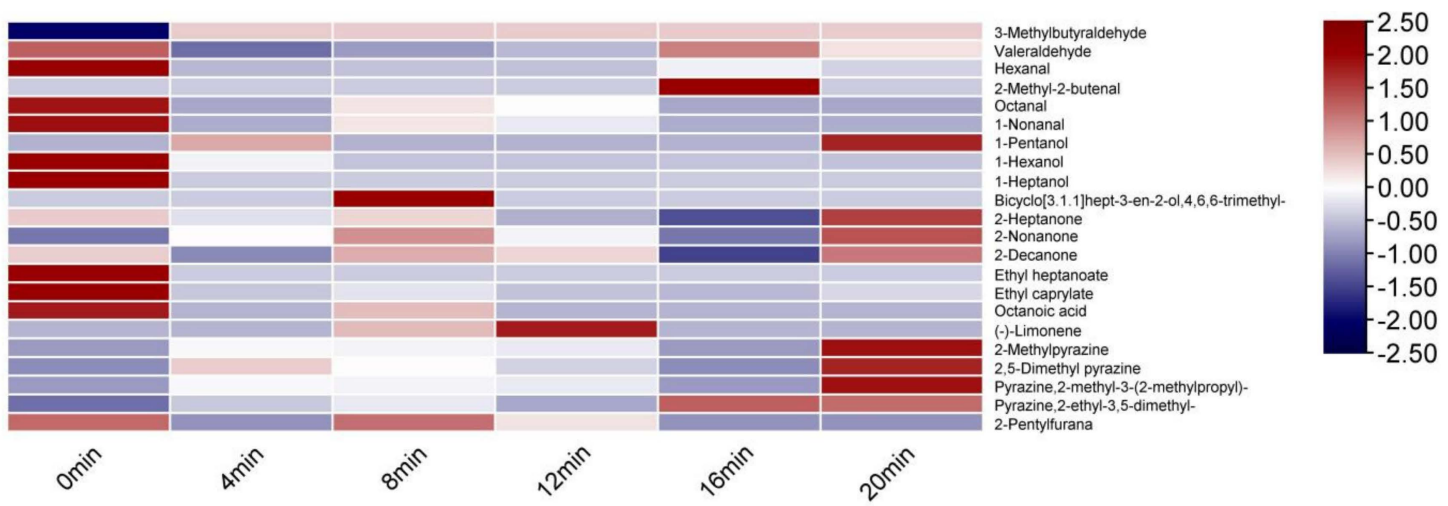

Figure 3. Heat map of ROAV of defatted tiger nut flour.

\subsection{E-Nose Analysis of Defatted Tiger Nut Flour}

It can be seen from Figure $4 \mathrm{~A}$ that the profile and area of the radar plot had some variation. The response intensity of the sensors W1C, W5C, W3S, W2W, and W3C was higher with slight variation, indicating that the contents of the aromatic compounds, benzene, ammonia, olefin, short-chain aromatic compounds, organic sulfides, and long-chain alkanes in the samples were high, but the changes were not significant. The sensors W2S, W1W, W6S, W1S and W5S changed significantly, indicating that baking had a significant effect on alcohols, aldehydes, ketones, sulfur compounds, hydrogen, nitrogen oxides and methyl components. This was related to the results of the above VOCs-the relative contents of 
alcohols, aldehydes, ketones, esters, and pyrazines were greater, and the changes were more significant.

A

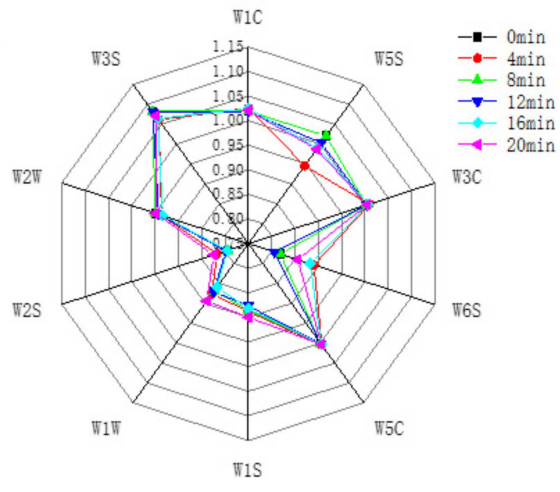

B

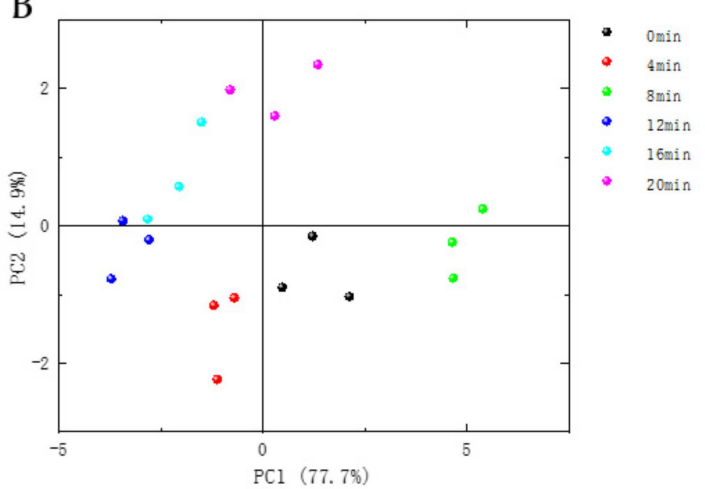

Figure 4. Radar diagram (A) and PCA (B) of defatted tiger nut flour for E-nose.

The PCA was performed to further analyze the odor differences of defatted tiger nut flour with different baking times. It can be seen from Figure $4 \mathrm{~B}$ that the contributions of PC1 and PC2 at different baking times were $77.7 \%$ and $14.9 \%$, respectively, with a cumulative contribution of $92.6 \%$, indicating that these two principal components could reflect most of the information of the samples. The defatted tiger nut flour without baking and with baking for 4 and $8 \mathrm{~min}$ were relatively close. For the sample baked for more than $8 \mathrm{~min}$, the radar plot distances were further from those of the unbaked sample, indicating that baking drastically changed the original odor of the defatted tiger nut flour. The samples baked for 16 and 20 min were relatively close, indicating that their odors were similar, and their sensory odors were mainly burnt and coffee aromas.

\subsection{E-Tongue Analysis of Defatted Tiger Nut Flour}

It can be seen from Figure 5 that the contributions of PC1 and PC2 were $44.2 \%$ and $28.6 \%$, respectively, with a cumulative contribution of $72.8 \%$, indicating that these two principal components could reflect most of the information of the samples. The plotted values for the unbaked and baked defatted tiger nut flour were far apart in the radar plots, indicating that baking significantly affected its taste. As the level of baking increased, the sensors AE1, C00 and GL1 changed significantly. This is because the sugar and amino acids in defatted tiger nut flour, as the flavor precursors of the Maillard reaction and caramelization, produced a caramel taste or bitterness and VOCs such as alcohols, aldehydes and pyrazines [42]. AAE, CT0 and CA0 showed umami, saltness and sourness, respectively, with slight changes.
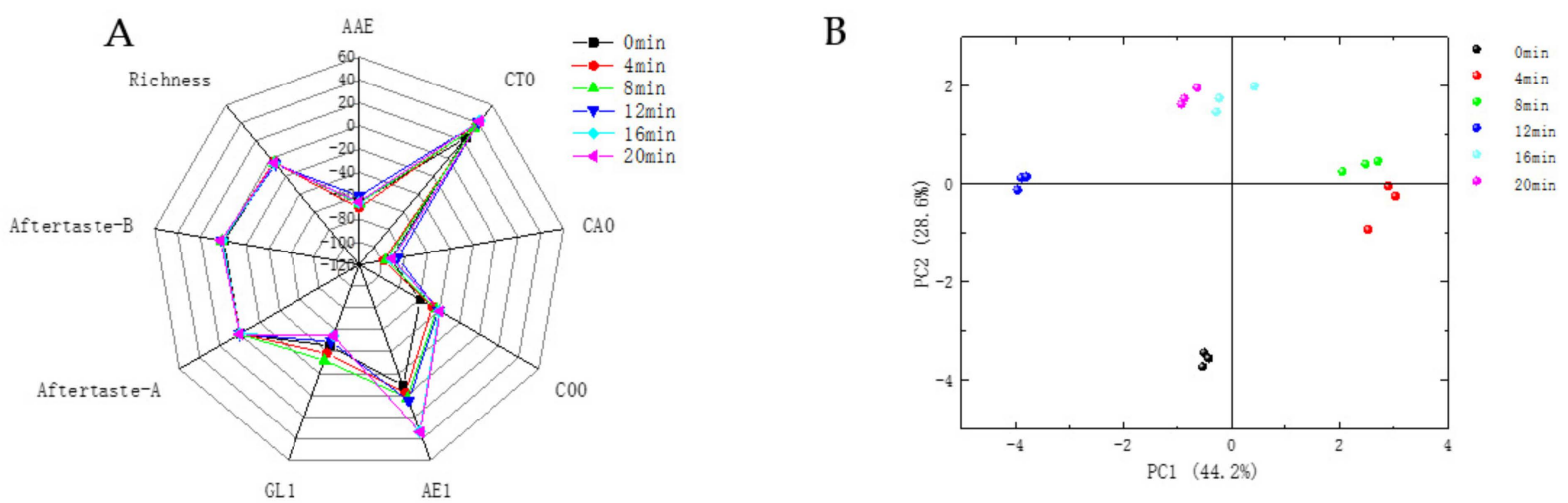

Figure 5. Radar diagram (A) and PCA (B) of defatted tiger nut flour for E-tongue. 
The radar plots of defatted tiger nut flour baked for 4 and 8 min were closer, indicating similar tastes. Their plots were far away from that for the unbaked defatted tiger nut flour, indicating that the taste was significantly different after baking. However, overbaking will cause the defatted tiger nut flour to produce unfavorable tastes such as astringency and bitterness, and produce coffee, burnt and other odors. When samples were baked for 12, 16 , and $20 \mathrm{~min}$, the respective defatted tiger nut flour radar plots were far away from that for the unbaked defatted tiger nut flour, and the samples began to develop bitterness; the sweetness decreased, and the overall taste worsened. According to the above, the VOCs, E-nose and E-tongue changed, the taste and odor of the defatted tiger nut flour were greatly changed at these baking times-its original flavor was lost, changing into a caramel and burnt flavor, indicating that its flavor decreased.

\section{Conclusions}

Tiger nut, as a high-quality oil-making raw material, will produce a large amount of defatted tiger nut flour after oil extraction [46]. Due to its reduced flavor, it is usually used as fertilizer and feed after oil extraction [47]. However, reasonable baking can effectively improve its flavor, and it can be used as a high-quality food raw material to realize its high-value utilization.

With the increase in baking level, the Maillard reaction, Strecker degradation, and caramelization consumed the sugar and amino acids in defatted tiger nut flour, resulting in a caramel taste or bitterness, while at the same time producing VOCs such as alcohols, aldehydes, pyrazines, etc. When the baking time exceeded $12 \mathrm{~min}$, the main odor changed to coffee and burnt odor, the color of the flour was too dark, and the quality was obviously reduced. When the flour was baked for $8 \mathrm{~min}$, the VOCs and key flavor compounds were the richest. The grass-like VOCs such as hexanal and 1-hexanol were reduced, and the VOCs of fruit, roasted peanuts, nuts, chocolate, milk, and sweet aromas such as $\gamma$-undecanolide, 1-dodecanol, (-)-limonene, 2-nonane, 2-tridecone, hexanoic acid, and pyrazines were increased. This indicates that a reasonable baking condition can improve the taste, aroma and flavor richness of defatted tiger nut flour.

This experiment showed that $8 \mathrm{~min}$ of baking can enhance the flavor of defatted tiger nut flour to compensate for the loss of flavor after oil extraction. Properly baked defatted tiger nut flour becomes a higher-quality food raw material. As a product that meets the needs of today's market, defatted tiger nut flour can be used to produce a wide variety of low-fat foods and help achieve the complete and high-value utilization of tiger nut resources.

Author Contributions: Conceptualization, C.G.; methodology, C.G.; software, C.G.; formal analysis, C.G.; investigation, D.W., Y.Z.; resources, D.W., Y.Z.; data curation, C.G.; writing-original draft preparation, C.G.; writing-review and editing, C.G.; visualization, C.G.; supervision, T.L. and Q.L.; project administration, T.L.; funding acquisition, D.W. All authors have read and agreed to the published version of the manuscript.

Funding: This research was funded by the Jilin Province Science and Technology Development Plan Program (20200502001NC).

Institutional Review Board Statement: Not applicable.

Informed Consent Statement: Not applicable.

Data Availability Statement: Data is shown in the article.

Conflicts of Interest: The authors declare no conflict of interest. 


\section{Appendix A}

Table A1. The sensor array of the E-nose.

\begin{tabular}{lll}
\hline & Sensor & General Description \\
\hline S1 & W1C & Sensitive to aromatic compounds, benzene \\
S2 & W5S & Highly sensitive to nitrogen oxides \\
S3 & W3C & Sensitive to aromatic compounds, ammonia \\
S4 & W6S & Sensitive to hydrogen \\
S5 & W5C & Sensitive to olefin, short-chain aromatic compounds \\
S6 & W1S & Sensitive to methyl \\
S7 & W1W & Sensitive to sulfur compounds \\
S8 & W2S & Sensitive to alcohols, aldehydes, and ketones \\
S9 & W2W & Sensitive to aromatic components, organic sulfides \\
S10 & W3S & Sensitive to long-chain alkanes \\
\hline
\end{tabular}

\section{Appendix B}

Table A2. The sensor array of the E-tongue.

\begin{tabular}{ll}
\hline Name of Detecting Electrodes & Characteristics \\
\hline CT0 & Saltiness \\
CA0 & Sourness \\
C00 & Bitterness, Aftertaste-B \\
GL1 & Sweetness \\
AE1 & Astringency, Aftertaste-A \\
AAE & Umami, Richness \\
\hline
\end{tabular}




\section{Appendix C}
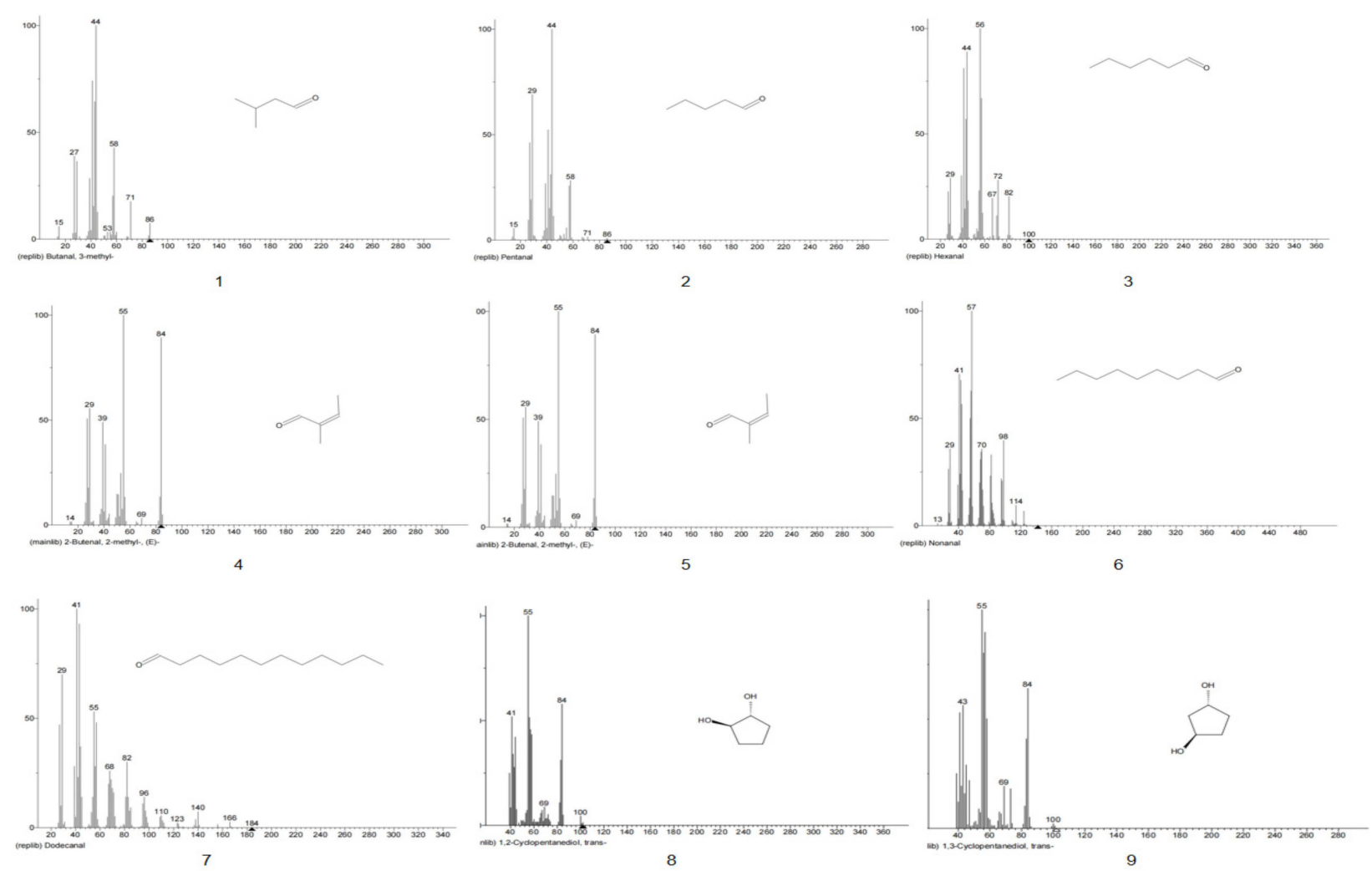

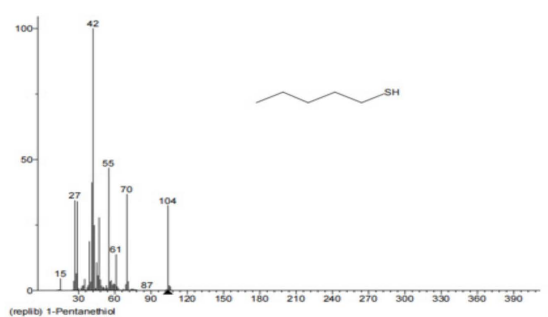

10

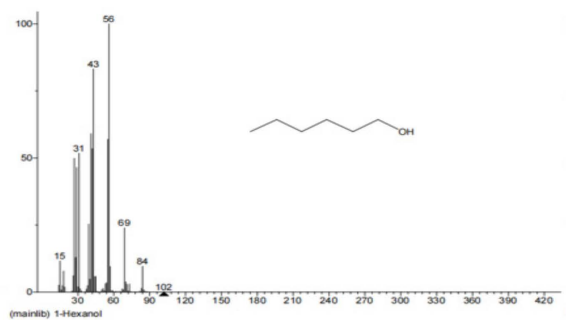

11

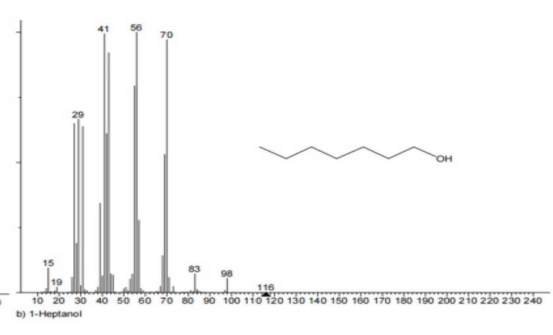

12

Figure A1. Cont. 


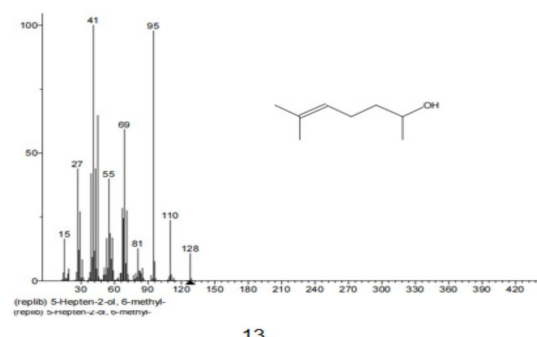

13
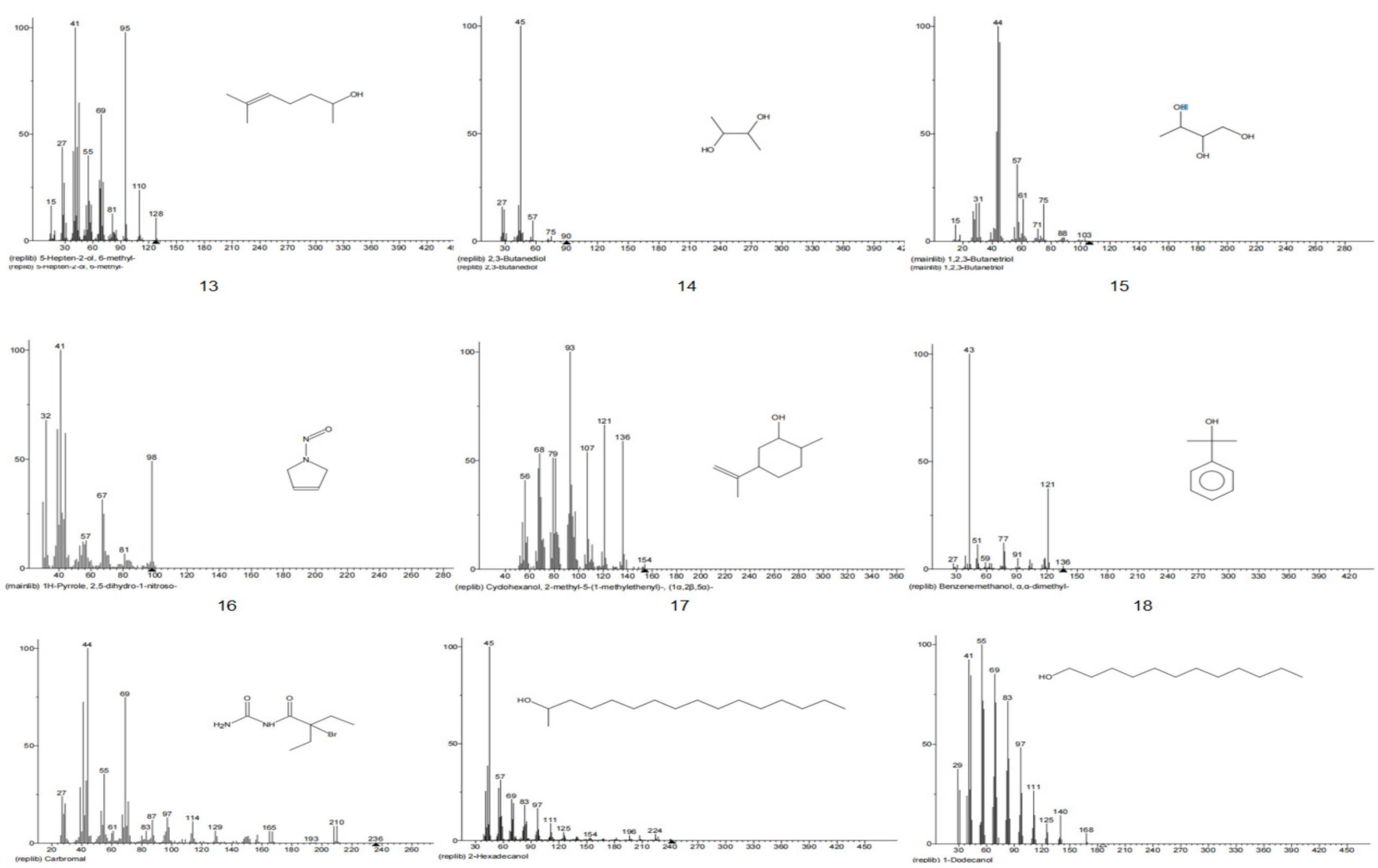

19

20

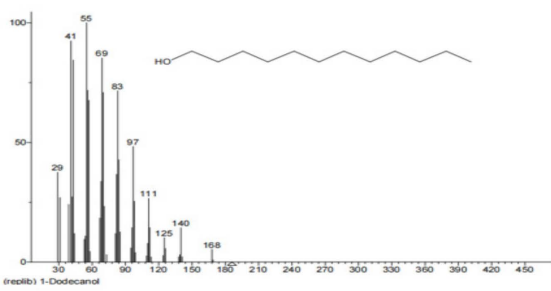

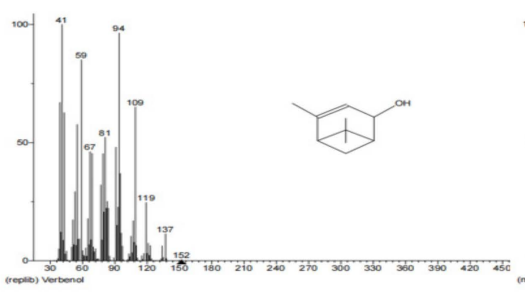

22

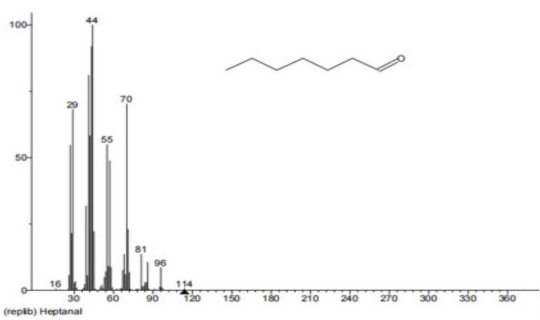

25
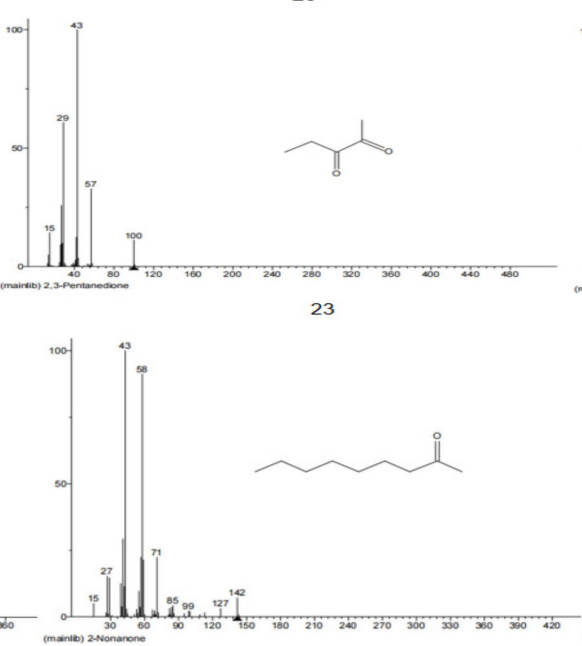

26
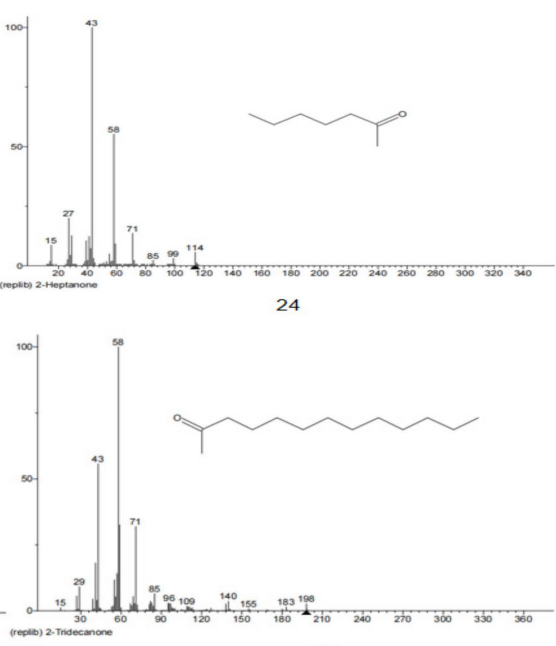

27

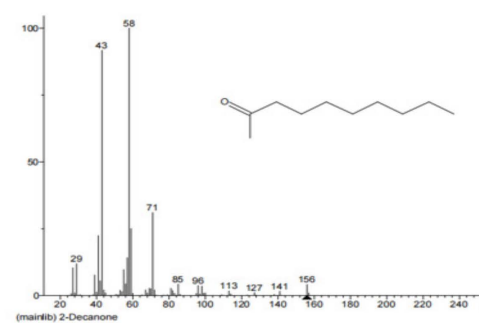

28

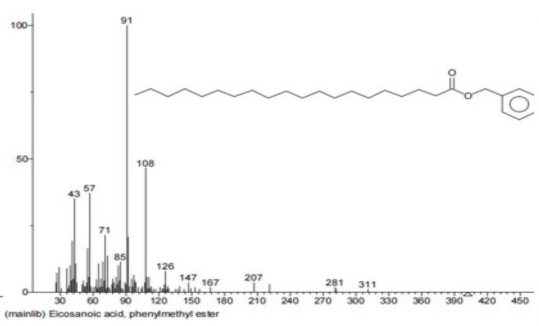

29

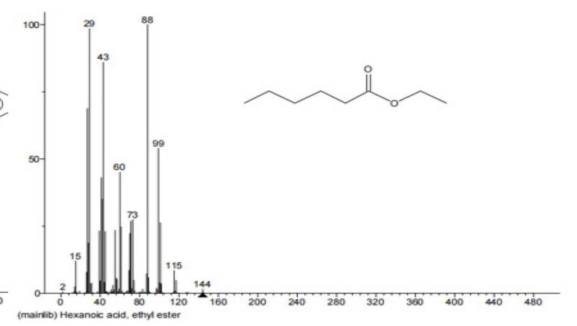

30

Figure A1. Cont. 


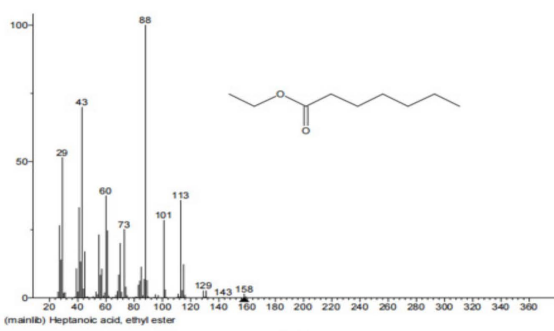

31

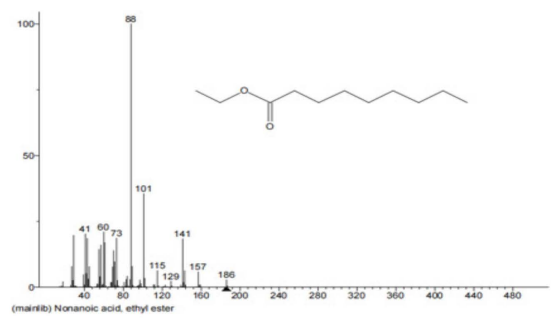

34

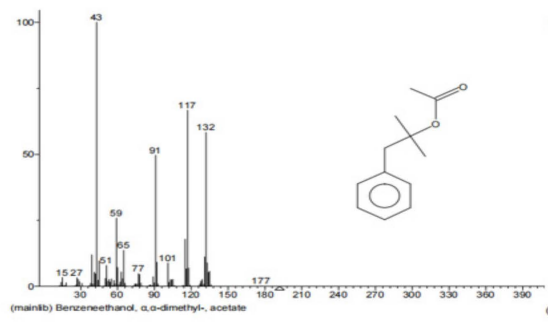

37

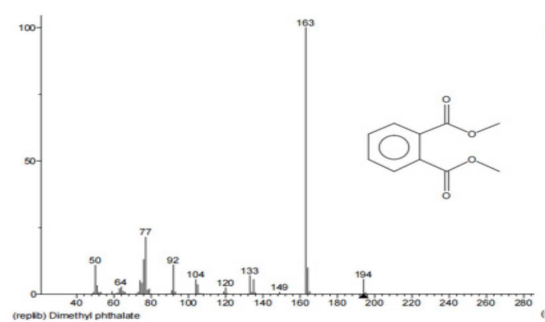

40
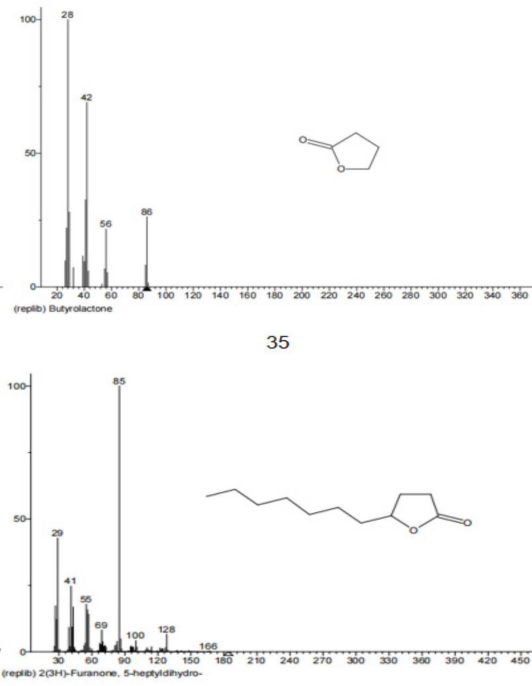

38

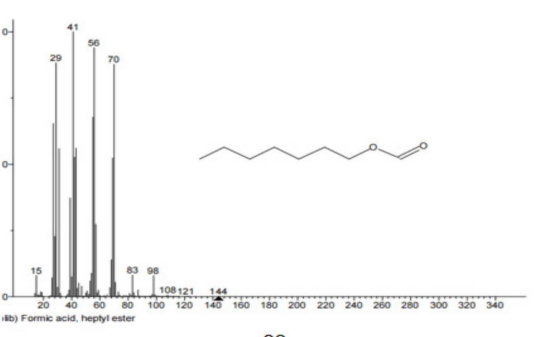

33

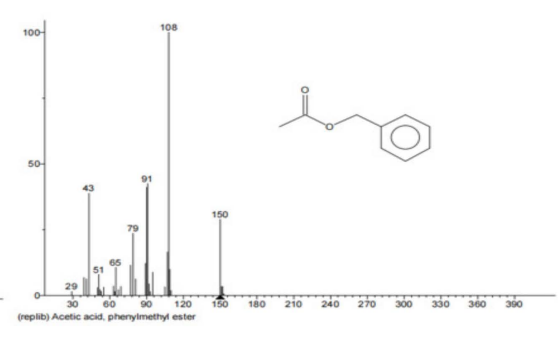

36

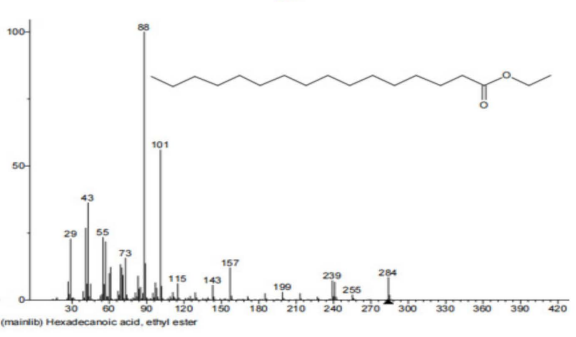

39

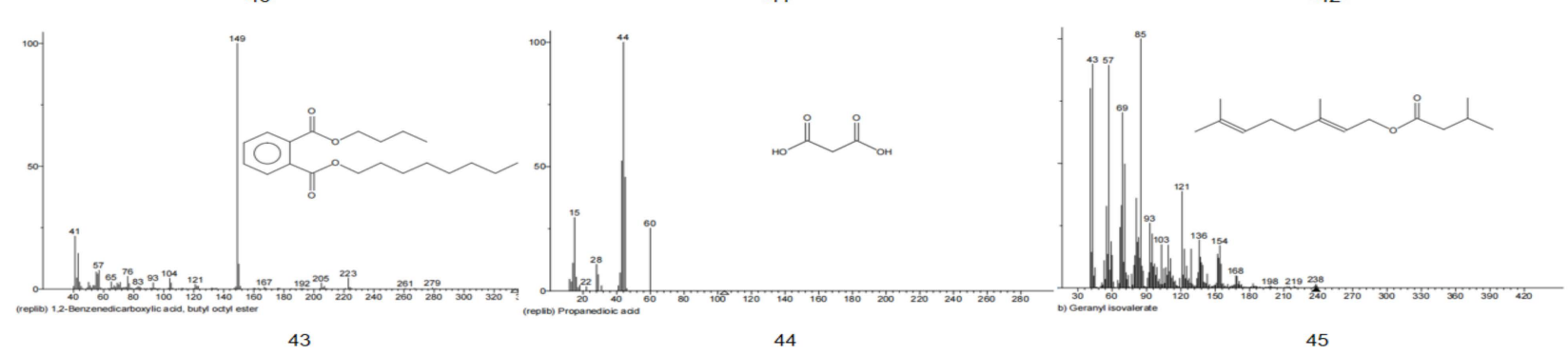

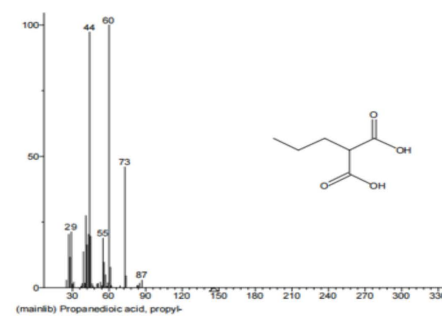

46

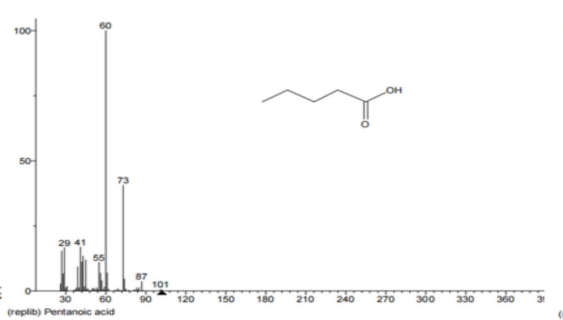

47

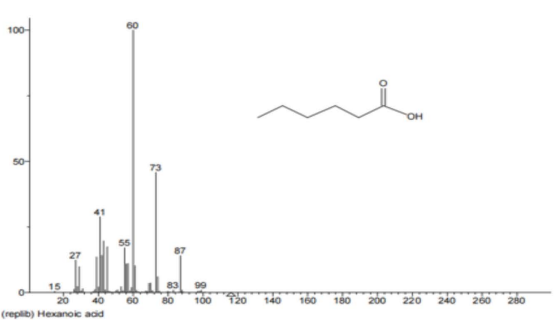

48

Figure A1. Cont. 


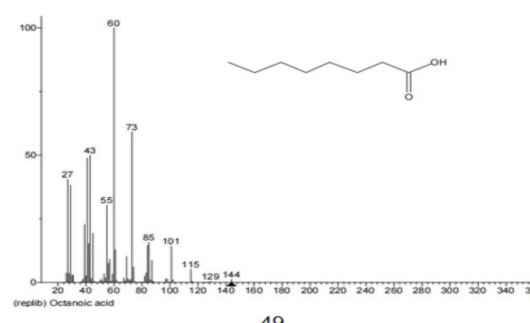

49
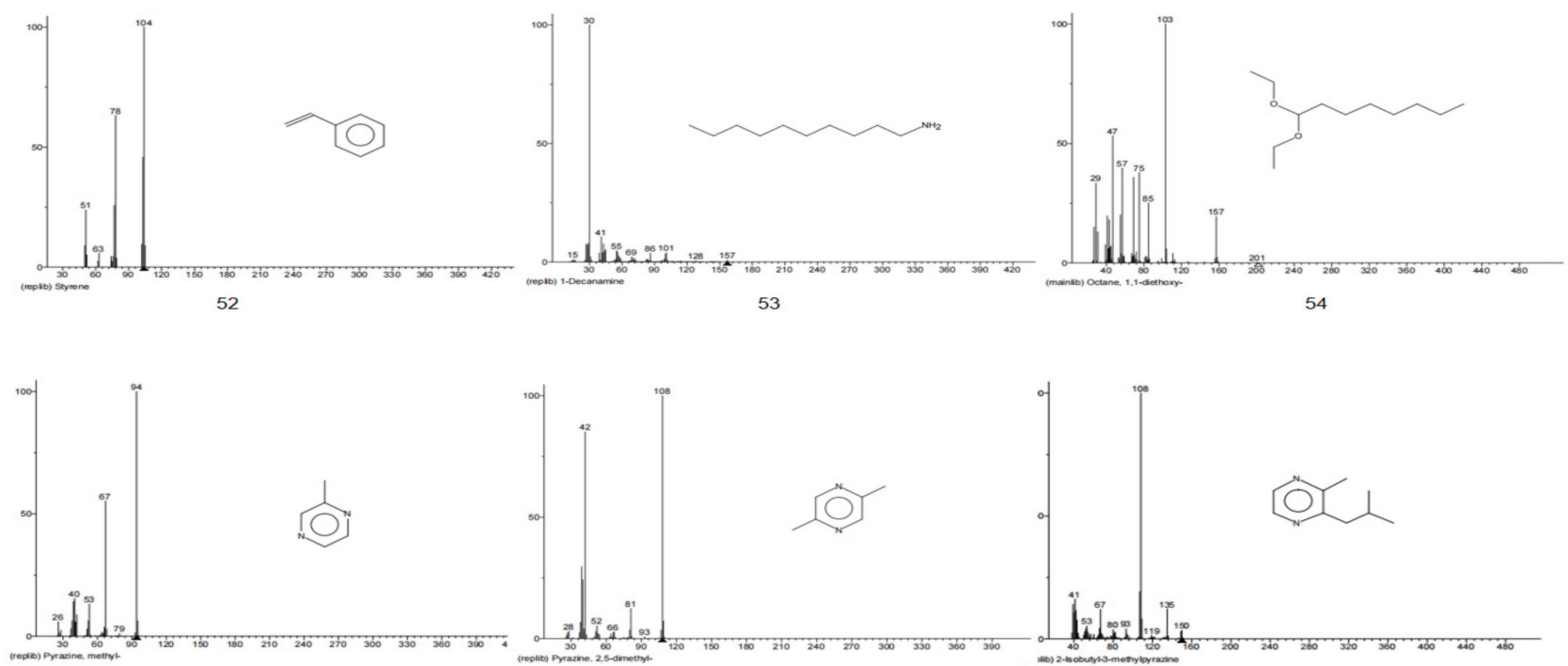

55
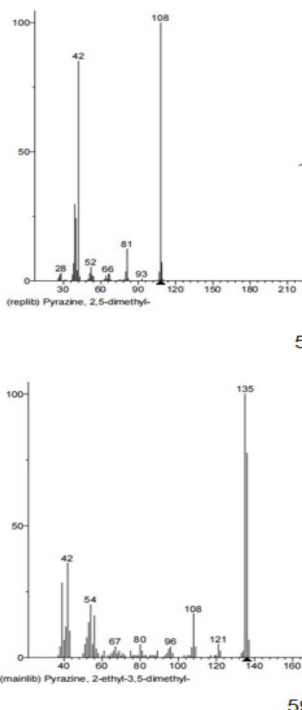

56

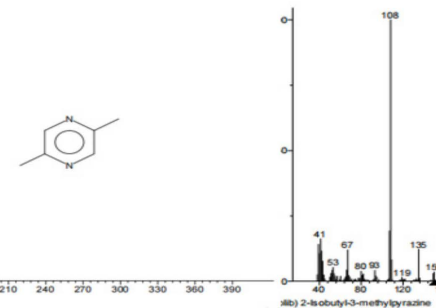

O

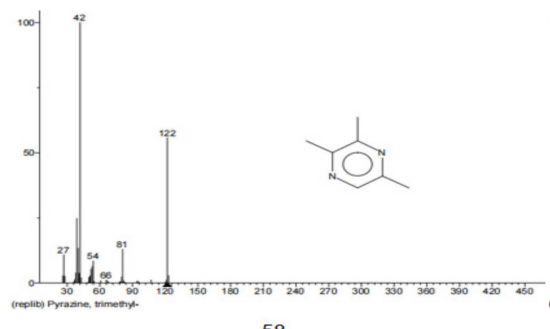

58
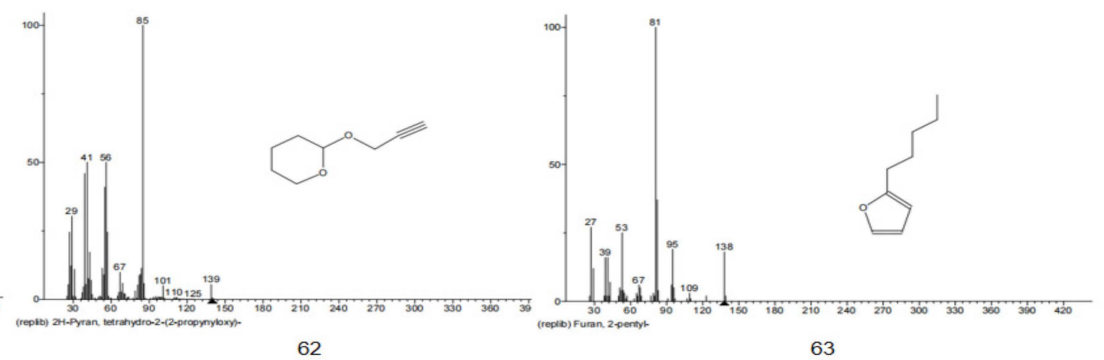

61

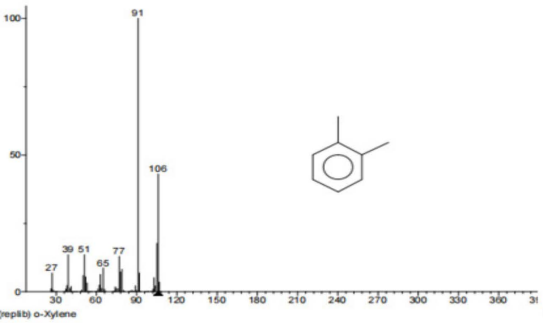

65

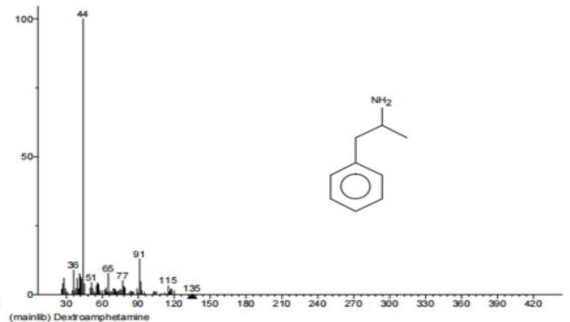

66

Figure A1. Cont. 


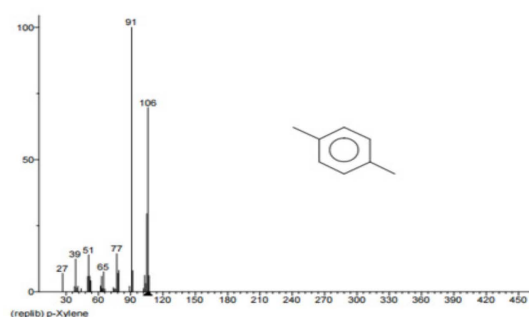

67

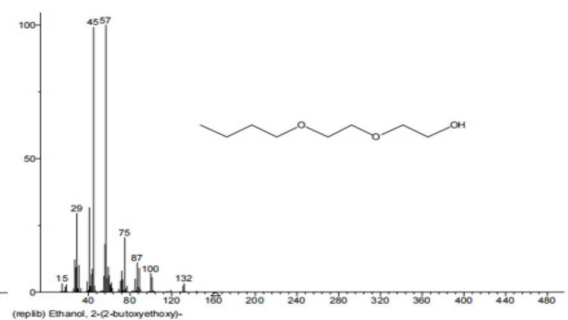

68

Figure A1. EI-MS fragments of defatted tiger nut flour.

\section{Appendix D}

Table A3. Metabolite chromatographic area of defatted tiger nut flour.

\begin{tabular}{|c|c|c|c|c|c|c|c|}
\hline \multirow{2}{*}{ Count } & \multirow{2}{*}{ Compounds } & \multicolumn{6}{|c|}{ Metabolite Chromatographic Area } \\
\hline & & $0 \mathrm{~min}$ & $4 \mathrm{~min}$ & $8 \mathrm{~min}$ & $12 \mathrm{~min}$ & $16 \mathrm{~min}$ & $20 \mathrm{~min}$ \\
\hline & Aldehydes & & & & & & \\
\hline 1 & 3-Methylbutyraldehyde & $\begin{array}{c}11,792,185 \pm \\
2,854,916^{\mathrm{f}}\end{array}$ & $\begin{array}{c}66,958,060 \pm \\
1,402,188^{a}\end{array}$ & $\begin{array}{c}25,558,481 \pm \\
578,827^{c}\end{array}$ & $\begin{array}{c}43,755,395 \pm \\
1,209,962^{\mathrm{b}}\end{array}$ & $\begin{array}{c}17,151,676 \pm \\
1,641,040 \mathrm{eb}\end{array}$ & $\begin{array}{r}20,085,417 \pm \\
1,074,126^{d}\end{array}$ \\
\hline 2 & Valeraldehyde & $\begin{array}{c}12,328,728 \pm \\
1,193,172^{c}\end{array}$ & $\begin{array}{r}13,254,495 \pm \\
3,471,841^{\mathrm{a}}\end{array}$ & $\begin{array}{c}6,853,643 \pm \\
620,083^{\mathrm{f}}\end{array}$ & $\begin{array}{c}11,555,485 \\
276,391\end{array}$ & $\begin{array}{c}13,002,353 \pm \\
1,723,130^{\mathrm{b}}\end{array}$ & $\begin{array}{c}9,116,002 \pm \\
989,242 \mathrm{e}\end{array}$ \\
\hline 3 & Hexanal & $\begin{array}{r}79,779,242 \pm \\
3,549,264 \mathrm{f}\end{array}$ & $\begin{array}{c}25,318,392 \pm \\
1,436,250^{\mathrm{a}}\end{array}$ & $\begin{array}{c}13,975,975 \pm \\
430,712^{\mathrm{d}}\end{array}$ & $\begin{array}{c}22,879,858 \pm \\
990,146^{\mathrm{b}}\end{array}$ & $\begin{array}{c}12,519,861 \pm \\
1,362,172 \mathrm{e}\end{array}$ & $\begin{array}{c}14,225,145 \pm \\
499,887^{c}\end{array}$ \\
\hline 4 & 2-Methyl-2-butenal & - & - & - & - & $\begin{array}{r}10,949,054 \pm \\
2,022,243^{\mathrm{a}}\end{array}$ & - \\
\hline 5 & Octanal & - & - & $\begin{array}{c}4,681,098 \pm \\
252,133^{\mathrm{b}}\end{array}$ & $\begin{array}{c}5,318,865 \pm \\
175,476^{\mathrm{a}}\end{array}$ & - & - \\
\hline 6 & 1-Nonanal & $\begin{array}{c}7,715,864 \pm \\
839,617^{a}\end{array}$ & - & $\begin{array}{c}3,629,976 \pm \\
271,877^{c}\end{array}$ & $\begin{array}{c}3,727,471 \pm \\
222,927^{b}\end{array}$ & - & - \\
\hline 7 & Dodecyl aldehyde & $\begin{array}{c}2,996,359 \pm \\
566,034^{\mathrm{a}}\end{array}$ & - & - & - & - & - \\
\hline 8 & $\begin{array}{c}\text { Alcohols } \\
1,2- \\
\text { Cyclopentanediol,(1R,2R)-rel- }\end{array}$ & $\begin{array}{c}10,273,253 \pm \\
1,925,406^{\mathrm{a}}\end{array}$ & - & - & - & - & - \\
\hline 9 & 1,3-Cyclopentanediol, trans & - & $\begin{array}{c}6,418,041 \pm \\
833,209^{a}\end{array}$ & - & - & - & - \\
\hline 10 & 1-Pentanol & - & $\begin{array}{c}28,087,409 \pm \\
396,453^{\mathrm{a}}\end{array}$ & - & - & - & $\begin{array}{c}15,065,364 \pm \\
339,365^{\mathrm{b}}\end{array}$ \\
\hline 11 & 1-Hexanol & $\begin{array}{c}14,580,062 \pm \\
1,367,430^{\mathrm{a}}\end{array}$ & $\begin{array}{l}8,659,778 \pm \\
1,588,293^{b}\end{array}$ & - & - & - & - \\
\hline 12 & 1-Heptanol & $\begin{array}{c}4,663,295 \pm \\
713,776^{\mathrm{a}}\end{array}$ & - & - & - & - & - \\
\hline 13 & 6-Methyl-5-hepten-2-ol & - & - & $\begin{array}{c}3,058,765 \pm \\
540,925^{\mathrm{b}}\end{array}$ & - & - & $\begin{array}{c}3,677,949 \pm \\
273,484^{\mathrm{a}}\end{array}$ \\
\hline 14 & 2,3-Butanediol & - & $\begin{array}{c}6,693,563 \pm \\
609,567^{\mathrm{a}}\end{array}$ & - & - & - & - \\
\hline 15 & 1,2,3-Butanetriol & $\begin{array}{c}7,340,648 \pm \\
1,314,908^{b}\end{array}$ & $\begin{array}{c}8,897,276 \pm \\
1,408,640^{a}\end{array}$ & - & $\begin{array}{c}2,972,566 \pm \\
531,916^{\mathrm{c}}\end{array}$ & - & - \\
\hline 16 & Furfuryl alcohol & - & - & - & - & - & $\begin{array}{c}1,950,106 \pm \\
152,721^{\mathrm{a}}\end{array}$ \\
\hline 17 & $\begin{array}{c}(1 \alpha, 2 \beta, 5 \alpha) 2-\text { Methyl-5-(1- } \\
\text { methylvinyl }) \\
\text { cyclohexanol }\end{array}$ & - & - & - & - & $\begin{array}{c}5,592,789 \pm \\
270,471^{\mathrm{a}}\end{array}$ & - \\
\hline 18 & $\begin{array}{c}\text { Alpha,alpha-dimethyl- } \\
\text { benzyl } \\
\text { alcohol }\end{array}$ & - & $\begin{array}{c}2,671,747 \pm \\
238,445^{\mathrm{b}}\end{array}$ & - & $\begin{array}{c}2,249,955 \pm \\
27,448^{c}\end{array}$ & $\begin{array}{c}5,424,527 \pm \\
164,274^{\mathrm{a}}\end{array}$ & $\begin{array}{c}1,560,790 \pm \\
39,400^{\mathrm{d}}\end{array}$ \\
\hline 19 & $\begin{array}{c}\text { Butanamide,N- } \\
\text { (aminocarbonyl)-2-bromo-2- } \\
\text { ethyl- }\end{array}$ & - & - & - & - & $\begin{array}{c}2,578,017 \pm \\
167,351^{\mathrm{a}}\end{array}$ & - \\
\hline 20 & 2-Hexadecanol & - & - & $\begin{array}{c}3,581,997 \pm \\
749,851^{\mathrm{a}}\end{array}$ & - & - & - \\
\hline
\end{tabular}


Table A3. Cont.

\begin{tabular}{|c|c|c|c|c|c|c|c|}
\hline \multirow{2}{*}{ Count } & \multirow{2}{*}{ Compounds } & \multicolumn{6}{|c|}{ Metabolite Chromatographic Area } \\
\hline & & $0 \mathrm{~min}$ & $4 \mathrm{~min}$ & $8 \mathrm{~min}$ & $12 \mathrm{~min}$ & $16 \mathrm{~min}$ & $20 \mathrm{~min}$ \\
\hline 21 & 1-Dodecanol & - & - & $\begin{array}{c}8,599,055 \pm \\
413,5544^{\mathrm{b}}\end{array}$ & $\begin{array}{c}8,241,799 \pm \\
692,477^{\mathrm{c}}\end{array}$ & $\begin{array}{c}10,935,789 \pm \\
277,967^{\mathrm{a}}\end{array}$ & $\begin{array}{c}3,595,720 \pm \\
550,123^{\mathrm{d}}\end{array}$ \\
\hline 22 & $\begin{array}{l}\text { Bicyclo[3.1.1]hept-3-en-2- } \\
\text { ol,4,6,6-trimethyl- } \\
\text { Ketones }\end{array}$ & - & - & $\begin{array}{c}3,071,251 \pm \\
437,217^{\mathrm{a}}\end{array}$ & - & - & - \\
\hline 23 & 2,3-Pentanedione & - & $\begin{array}{c}7,866,256 \pm \\
204,624^{\mathrm{a}}\end{array}$ & - & - & - & - \\
\hline 24 & 2-Heptanone & $\begin{array}{r}7,019,712 \pm \\
2,395,912 \mathrm{e}\end{array}$ & $\begin{array}{c}16,903,971 \pm \\
3,153,722^{\text {a }}\end{array}$ & $\begin{array}{c}9,675,887 \pm \\
755,396^{\mathrm{c}}\end{array}$ & $\begin{array}{c}7,603,704 \pm \\
781,266^{\mathrm{d}}\end{array}$ & - & $\begin{array}{c}12,132,543 \pm \\
572,100^{\mathrm{b}}\end{array}$ \\
\hline 25 & Heptaldehyde & - & - & - & $\begin{array}{c}2,299,077 \pm \\
209,386\end{array}$ & - & - \\
\hline 26 & 2-Nonanone & - & $\begin{array}{c}14,118,026 \pm \\
255,105^{\mathrm{a}}\end{array}$ & $\begin{array}{c}9,859,106 \pm \\
412,861^{\mathrm{c}}\end{array}$ & $\begin{array}{c}10,813,666 \pm \\
79,431^{\mathrm{b}}\end{array}$ & - & $\begin{array}{c}8,686,225 \pm \\
356,732 \mathrm{~d}\end{array}$ \\
\hline 27 & 2-Tridecanone & - & - & - & - & - & $\begin{array}{c}3,788,860 \pm \\
149,410^{\text {a }}\end{array}$ \\
\hline 28 & 2-Decanone & $\begin{array}{c}5,442,684 \pm \\
153,060^{\mathrm{d}}\end{array}$ & $\begin{array}{c}5,330,997 \pm \\
496,588 \mathrm{e}^{\mathrm{e}}\end{array}$ & $\begin{array}{c}7,659,657 \pm \\
623,602^{\mathrm{b}}\end{array}$ & $\begin{array}{c}19,850,564 \pm \\
3,329,870^{a}\end{array}$ & - & $\begin{array}{c}6,321,176 \pm \\
136,924^{\mathrm{c}}\end{array}$ \\
\hline & Esters & & & & & & \\
\hline 29 & Arachic acid benzyl ester & - & - & - & - & - & $\begin{array}{c}10,994,925 \pm \\
1,202,986^{\mathrm{a}}\end{array}$ \\
\hline 30 & Ethyl caproate & $\begin{array}{r}68,912,252 \pm \\
4,890,018^{\text {a }}\end{array}$ & $\begin{array}{c}59,082,777 \pm \\
4,334,477^{\mathrm{b}}\end{array}$ & $\begin{array}{c}9,580,383 \pm \\
395,585^{\mathrm{e}}\end{array}$ & $\begin{array}{c}5,626,718 \pm \\
323,192{ }^{\mathrm{f}}\end{array}$ & $\begin{array}{c}15,778,964 \pm \\
1,745,053^{\mathrm{d}}\end{array}$ & $\begin{array}{c}37,619,477 \pm \\
847,233^{c}\end{array}$ \\
\hline 31 & Ethyl heptanoate & $\begin{array}{c}9,559,224 \pm \\
1,021,695^{\mathrm{a}}\end{array}$ & - & - & - & - & - \\
\hline 32 & Ethyl caprylate & $\begin{array}{c}37,292,353 \pm \\
9,104,355^{\mathrm{a}}\end{array}$ & $\begin{array}{c}5,415,206 \pm \\
367,312^{\mathrm{c}}\end{array}$ & $\begin{array}{c}6,785,121 \pm \\
486,156^{\mathrm{b}}\end{array}$ & $\begin{array}{c}2,451,390 \pm \\
130,915^{\mathrm{e}}\end{array}$ & - & $\begin{array}{c}3,425,805 \pm \\
333,257^{\mathrm{d}}\end{array}$ \\
\hline 33 & Hexyl formate & - & $\begin{array}{c}4,804,898 \pm \\
456,699^{a}\end{array}$ & - & - & - & - \\
\hline 34 & Ethyl nonanoate & $\begin{array}{c}28,577,271 \pm \\
2,288,009 \text { a }\end{array}$ & - & - & - & - & - \\
\hline 35 & $\gamma$-Butyrolactone & - & $\begin{array}{c}7,026,474 \pm \\
230,187^{\mathrm{b}}\end{array}$ & $\begin{array}{c}6,776,864 \pm \\
103,466^{\mathrm{d}}\end{array}$ & $\begin{array}{c}6,840,893 \pm \\
764,429^{c}\end{array}$ & - & $\begin{array}{c}9,143,145 \pm \\
240,747^{\text {a }}\end{array}$ \\
\hline 36 & Benzyl acetate & - & - & - & - & $\begin{array}{c}5,388,247 \pm \\
228,763^{\mathrm{a}}\end{array}$ & - \\
\hline 37 & Arachic acid benzyl ester & - & - & - & - & $\begin{array}{c}2,473,166 \pm \\
161,706^{\mathrm{a}}\end{array}$ & - \\
\hline 38 & $\gamma$-U-ecanolactone & $\begin{array}{c}3,044,967 \pm \\
139,525^{\mathrm{b}}\end{array}$ & $\begin{array}{c}2,816,819 \pm \\
771,128^{\mathrm{c}}\end{array}$ & $\begin{array}{c}5,172,774 \pm \\
318,146^{\mathrm{a}}\end{array}$ & $\begin{array}{c}2,364,849 \pm \\
451,147^{\mathrm{d}}\end{array}$ & - & \\
\hline 39 & Ethyl palmitate & $\begin{array}{c}9,939,285 \pm \\
976,759^{\mathrm{b}}\end{array}$ & - & $\begin{array}{c}16,623,361 \pm \\
628,505^{\mathrm{a}}\end{array}$ & $\begin{array}{c}7,094,880 \pm \\
304,630^{\mathrm{c}}\end{array}$ & - & $\begin{array}{c}1,749,057 \pm \\
149,315^{\mathrm{d}}\end{array}$ \\
\hline 40 & Dimethyl phthalate & $\begin{array}{c}8,036,946 \pm \\
993,794^{\mathrm{d}}\end{array}$ & $\begin{array}{c}4,421,546 \pm \\
692,111^{\mathrm{e}}\end{array}$ & $\begin{array}{c}30,910,696 \pm \\
550,872^{\text {a }}\end{array}$ & $\begin{array}{c}11,128,227 \\
337,048^{\mathrm{b}}\end{array}$ & $\begin{array}{c}9,079,978 \pm \\
146,937^{\mathrm{c}}\end{array}$ & $\begin{array}{c}4,015,313 \pm \\
217,464^{\mathrm{f}}\end{array}$ \\
\hline 41 & Ethyl oleate & $\begin{array}{c}6,533,353 \pm \\
353,295^{c}\end{array}$ & $\begin{array}{c}2,562,580 \pm \\
170,496^{\mathrm{d}}\end{array}$ & $\begin{array}{c}16,803,248 \pm \\
133,139^{\mathrm{a}}\end{array}$ & $\begin{array}{c}8,270,314 \pm \\
555,643^{\mathrm{b}}\end{array}$ & - & - \\
\hline 42 & Ethyl linoleate & - & - & $\begin{array}{c}5,342,733 \pm \\
761,636^{\mathrm{a}}\end{array}$ & - & - & - \\
\hline 43 & Diisobutyl phthalate & - & - & $\begin{array}{c}15,985,501 \pm \\
574,543^{\text {a }}\end{array}$ & - & - & - \\
\hline & Acids & & & & & & \\
\hline 44 & Malonic acid & $\begin{array}{c}7,257,275 \pm \\
984,808^{\text {a }}\end{array}$ & - & - & - & - & - \\
\hline 45 & $\begin{array}{c}\text { 3-Methyl-,3,7-dimethyl-2,6- } \\
\text { octadienyl ester,(E)-Butanoic } \\
\text { acid }\end{array}$ & 然- & - & $\begin{array}{c}a 5,562,894 \pm \\
567,289^{a}\end{array}$ & - & - & - \\
\hline 46 & 2-Propylmalonic acid & $\begin{array}{c}6,711,452 \pm \\
1,532,775^{\mathrm{a}}\end{array}$ & - & - & - & - & - \\
\hline 47 & Valeric acid & $\begin{array}{c}10,687,396 \pm \\
1,427,136^{\mathrm{a}}\end{array}$ & $\begin{array}{c}3,054,025 \pm \\
495,506^{\mathrm{b}}\end{array}$ & - & - & - & - \\
\hline 48 & Hexanoic acid & - & - & $\begin{array}{c}8,132,140 \pm \\
426,480^{\text {a }}\end{array}$ & $\begin{array}{c}3,153,899 \pm \\
424,842^{\mathrm{c}}\end{array}$ & - & $\begin{array}{c}7,729,154 \pm \\
226,647^{\mathrm{b}}\end{array}$ \\
\hline 49 & Octanoic acid & $\begin{array}{c}7,099,170 \pm \\
194,137^{\mathrm{a}}\end{array}$ & - & $\begin{array}{c}5,565,560 \pm \\
1,435,562^{\mathrm{b}}\end{array}$ & - & - & - \\
\hline 50 & $\begin{array}{l}\text { Nonanoic acid } \\
\text { Olefins }\end{array}$ & $\begin{array}{c}4,302,954 \pm \\
195,209^{\text {a }}\end{array}$ & - & $\begin{array}{c}3,469,377 \pm \\
175,199^{\mathrm{b}}\end{array}$ & - & - & - \\
\hline
\end{tabular}


Table A3. Cont.

\begin{tabular}{|c|c|c|c|c|c|c|c|}
\hline \multirow{2}{*}{ Count } & \multirow{2}{*}{ Compounds } & \multicolumn{6}{|c|}{ Metabolite Chromatographic Area } \\
\hline & & $0 \mathrm{~min}$ & $4 \mathrm{~min}$ & $8 \mathrm{~min}$ & $12 \mathrm{~min}$ & $16 \mathrm{~min}$ & $20 \mathrm{~min}$ \\
\hline 51 & (-)-Limonene & - & - & $\begin{array}{c}4,131,493 \pm \\
932,135^{\mathrm{b}}\end{array}$ & $\begin{array}{c}14,250,738 \pm \\
315,018^{\mathrm{a}}\end{array}$ & - & - \\
\hline 52 & Phenylethylene & $\begin{array}{c}37,340,219 \pm \\
2,949,898^{\mathrm{a}}\end{array}$ & - & $\begin{array}{c}19,210,526 \pm \\
639,833^{\mathrm{b}}\end{array}$ & $\begin{array}{c}13,823,767 \pm \\
700,161^{\mathrm{d}}\end{array}$ & $\begin{array}{r}17,590,988 \pm \\
1,109,361^{\mathrm{c}}\end{array}$ & - \\
\hline & Alkanes & & & & & & \\
\hline 53 & Decylamine & - & - & - & - & - & $\begin{array}{c}4,346,195 \pm \\
439,297^{\text {a }}\end{array}$ \\
\hline 54 & 1,1-Diethoxy-octane & $\begin{array}{l}2,188,751 \pm \\
368,020^{a}\end{array}$ & - & - & - & - & - \\
\hline & Pyrazines & & & & & & \\
\hline 55 & 2-Methylpyrazine & - & $\begin{array}{c}10,441,853 \pm \\
648,013^{\mathrm{b}}\end{array}$ & $\begin{array}{c}4,142,044 \pm \\
278,044^{\mathrm{d}}\end{array}$ & $\begin{array}{c}6,436,952 \pm \\
377,356^{c}\end{array}$ & - & $\begin{array}{c}10,748,816 \pm \\
462,731^{\mathrm{a}}\end{array}$ \\
\hline 56 & 2,5-Dimethyl pyrazine & - & $\begin{array}{c}31,783,456 \pm \\
5,448,943^{\mathrm{a}}\end{array}$ & $\begin{array}{l}8,468,775 \pm \\
2,207,879^{d}\end{array}$ & $\begin{array}{c}8,811,310 \pm \\
570,516^{\mathrm{c}}\end{array}$ & - & $\begin{array}{l}17,449,646 \pm \\
627,200^{b}\end{array}$ \\
\hline 57 & $\begin{array}{l}\text { Pyrazine,2-methyl-3-(2- } \\
\text { methylpropyl)- }\end{array}$ & - & $\begin{array}{c}2,553,673 \pm \\
403,754^{\mathrm{b}}\end{array}$ & $\begin{array}{c}2,288,035 \pm \\
171,640^{\mathrm{c}}\end{array}$ & - & - & $\begin{array}{c}2,562,403 \pm \\
403,020 \mathrm{a}\end{array}$ \\
\hline 58 & 2,3,5-Trimethylpyrazine & - & $\begin{array}{l}2,781,717 \pm \\
348,256^{\mathrm{a}}\end{array}$ & - & - & - & $\begin{array}{c}2,105,884 \pm \\
283,159^{b}\end{array}$ \\
\hline 59 & $\begin{array}{c}\text { Pyrazine,2-ethyl-3,5- } \\
\text { dimethyl } \\
\text { Other }\end{array}$ & - & $\begin{array}{r}8,306,729 \pm \\
2,108,82^{a}\end{array}$ & $\begin{array}{c}4,469,916 \pm \\
507,365^{\mathrm{d}}\end{array}$ & $\begin{array}{c}3,928,670 \pm \\
492,67 \mathrm{e}^{\mathrm{e}}\end{array}$ & $\begin{array}{c}4,614,976 \pm \\
336,516^{c}\end{array}$ & $\begin{array}{c}7,382,020 \pm \\
77,193^{b}\end{array}$ \\
\hline 60 & Toluene & - & - & $\begin{array}{c}13,651,178 \pm \\
700,810^{\mathrm{b}}\end{array}$ & $\begin{array}{c}11,227,668 \pm \\
615,214^{c}\end{array}$ & $\begin{array}{r}21,142,789 \pm \\
2,075,904^{\mathrm{a}}\end{array}$ & - \\
\hline 61 & 1,2-Xylene & - & - & - & - & $\begin{array}{c}35,065,628 \pm \\
13,206,967^{a}\end{array}$ & - \\
\hline 62 & (+)-Phenaminum & - & - & - & - & - & $\begin{array}{c}3,101,526 \pm \\
253,943^{a}\end{array}$ \\
\hline 63 & 1,4-Xylene & $\begin{array}{c}23,391,467 \pm \\
1,275,672^{\mathrm{a}}\end{array}$ & - & - & $\begin{array}{l}3,251,724 \pm \\
259,873^{b}\end{array}$ & - & - \\
\hline 64 & 2-Pentylfuran & $\begin{array}{c}2,736,420 \pm \\
158,086^{c}\end{array}$ & - & $\begin{array}{c}3,780,418 \pm \\
39,076^{b}\end{array}$ & $\begin{array}{c}4,192,335 \pm \\
466,282^{a}\end{array}$ & - & - \\
\hline 65 & Butyldiglycol & - & $\begin{array}{l}6,400,411^{ \pm} \\
518,291^{\mathrm{b}}\end{array}$ & $\begin{array}{c}3,598,558 \pm \\
445,427^{\mathrm{d}}\end{array}$ & $\begin{array}{l}5,714,445 \pm \\
302,624^{\mathrm{c}}\end{array}$ & $\begin{array}{c}13,857,534 \pm \\
761,673^{a}\end{array}$ & $\begin{array}{c}3,444,407 \pm \\
206,099 \mathrm{e}^{-}\end{array}$ \\
\hline 66 & 2-Acetyl pyrrole & - & - & - & $\begin{array}{c}1,234,838 \pm \\
37,017^{\mathrm{a}}\end{array}$ & - & $\begin{array}{c}3,595,720 \pm \\
550,123^{b}\end{array}$ \\
\hline 67 & $\begin{array}{l}\text { 2H-Pyran,tetrahydro } \\
\text {-2-(2-propyn-1-yloxy)- }\end{array}$ & - & - & $\begin{array}{c}9,303,984 \pm \\
499,986^{\mathrm{a}}\end{array}$ & - & - & - \\
\hline 68 & $\begin{array}{l}\text { 4-Hydroxy-3- } \\
\text { methoxystyrene }\end{array}$ & - & - & $\begin{array}{c}11,222,926 \pm \\
636,901^{\mathrm{a}}\end{array}$ & - & - & $\begin{array}{c}3,651,377 \pm \\
354,222^{b}\end{array}$ \\
\hline
\end{tabular}

\section{References}

1. Yeboah, S.O.; Mitei, Y.C.; Ngila, J.C.; Wessjohann, L.; Schmidt, J. Compositional and Structural Studies of the Oils from Two Edible Seeds: Tiger Nut, Cyperus Esculentum, and Asiato, Pachira Insignis, from Ghana. Food Res. Int. 2012, 47, 259-266. [CrossRef]

2. Codina-Torrella, I.; Guamis, B.; Trujillo, A.J. Characterization and Comparison of Tiger Nuts (Cyperus esculentus L.) from Different Geographical Origin. Ind. Crops Prod. 2015, 65, 406-411. [CrossRef]

3. Lasekan, O.; Abdulkarim, S.M. Extraction of Oil from Tiger Nut (Cyperus esculentus L.) with Supercritical Carbon Dioxide (Sc-CO $)_{2}$. LWT Food Sci. Technol. 2012, 47, 287-292. [CrossRef]

4. Guo, T.; Wan, C.; Huang, F.; Wei, C. Evaluation of Quality Properties and Antioxidant Activities of Tiger Nut (Cyperus esculentus L.) Oil Produced by Mechanical Expression or/with Critical Fluid Extraction. LWT 2021, 141, 110915. [CrossRef]

5. Vega-Morales, T.; Mateos-Diaz, C.; Perez-Machin, R.; Wiebe, J.; Gericke, N.P.; Alarcon, C.; Lopez-Romero, J.M. Chemical Composition of Industrially and Laboratory Processed Cyperus Esculentus Rhizomes. Food Chem. 2019, 297, 170. [CrossRef]

6. Cui, Q.; Wang, L.; Wang, G.; Zhang, A.; Wang, X.; Jiang, L. Ultrasonication Effects on Physicochemical and Emulsifying Properties of Cyperus Esculentus Seed (Tiger Nut) Proteins. LWT 2021, 142, 110979. [CrossRef]

7. Dun, Q.; Yao, L.; Deng, Z.; Li, H.; Li, J.; Fan, Y.; Zhang, B. Effects of Hot and Cold-Pressed Processes on Volatile Compounds of Peanut Oil and Corresponding Analysis of Characteristic Flavor Components. LWT 2019, 112, 107648. [CrossRef]

8. Paravisini, L.; Prot, A.; Gouttefangeas, C.; Moretton, C.; Nigay, H.; Dacremont, C.; Guichard, E. Characterisation of the Volatile Fraction of Aromatic Caramel Using Heart-Cutting Multidimensional Gas Chromatography. Food Chem. 2015, 167, 281-289. [CrossRef]

9. Panagiota, Z.; Fotini, P.; Anthia, M.; Evdoxiamaria, V.; Georgios, B.; Adamantini, P. Single Origin Coffee Aroma: From Optimized Flavor Protocols and Coffee Customization to Instrumental Volatile Characterization and Chemometrics. Molecules 2021, 26, 4609. 
10. Valdés García, A.; Sánchez Romero, R.; Juan Polo, A.; Prats Moya, S.; Maestre Pérez, S.E.; Beltrán Sanahuja, A. Volatile Profile of Nuts, Key Odorants and Analytical Methods for Quantification. Foods 2021, 10, 1611. [CrossRef]

11. Yahya, H.; Linforth, R.S.T.; Cook, D.J. Flavour Generation during Commercial Barley and Malt Roasting Operations: A Time Course Study. Food Chem. 2014, 145, 378-387. [CrossRef]

12. Zołnierczyk, A.K.; Szumny, A.A. Sensory and Chemical Characteristic of Two Insect Species: Tenebrio Molitor and Zophobas Morio Larvae Affected by Roasting Processes. Molecules 2021, 26, 2697. [CrossRef]

13. Aboud, S.A.; Altemimi, A.B.; Al-Hiiphy, A.R.S.; Yi-Chen, L.; Cacciola, F.A. Comprehensive Review on Infrared Heating Applications in Food Processing. Molecules 2019, 24, 4125. [CrossRef]

14. Laureati, M.; Buratti, S.; Bassoli, A.; Borgonovo, G.; Pagliarini, E. Discrimination and Characterisation of Three Cultivars of Perilla Frutescens by Means of Sensory Descriptors and Electronic Nose and Tongue Analysis. Food Res. Int. 2010, 43, 959-964. [CrossRef]

15. Claudia, G.V.; Eden, T.; Sigfredo, F. Integrating A Low-Cost Electronic Nose and Machine Learning Modelling to Assess Coffee Aroma Profile and Intensity. Sensors 2021, 21, 2016.

16. Chen, J.; Tao, L.; Zhang, T.; Zhang, J.; Wu, T.; Luan, D.; Ni, L.; Wang, X.; Zhong, J. Effect of Four Types of Thermal Processing Methods on the Aroma Profiles of Acidity Regulator-Treated Tilapia Muscles Using E-Nose, Hs-Spme-Gc-Ms, and Hs-Gc-Ims. LWT 2021, 147, 111585. [CrossRef]

17. Yi, C.; Li, Y.; Zhu, H.; Liu, Y.; Quan, K. Effect of Lactobacillus Plantarum Fermentation on the Volatile Flavors of Mung Beans. LWT 2021, 146, 111434. [CrossRef]

18. Cai, W.C.; Tang, F.X.; Guo, Z. Effects of Pretreatment Methods and Leaching Methods on Jujube Wine Quality Detected by Electronic Senses and Hs-Spme-Gc-Ms. Food Chem. 2020, 330, 127330. [CrossRef]

19. Ye, T.T.; Liu, J.; Wan, P.; Liu, S.Y.; Wang, Q.Z.; Chen, D.W. Investigation of The Effect of Polar Components in Cream on the Flavor of Heated Cream Based on Nmr and Gc-Ms Methods. LWT 2022, 155, 112940. [CrossRef]

20. Zhang, Y.; Li, X.; Lu, X.; Sun, H.; Wang, F. Effect of Oilseed Roasting on the Quality, Flavor and Safety of Oil: A Comprehensive Review. Food Res. Int. 2021, 150, 110791. [CrossRef]

21. Li, X.Z.; Liu, S.Q. Effect of Ph, Xylose Content and Heating Temperature on Colour and Flavour Compound Formation of Enzymatically Hydrolysed Pork Trimmings. LWT 2021, 150, 112017. [CrossRef]

22. Kasote, D.; Singh, V.K.; Bollinedi, H.; Singh, A.K.; Sreenivasulu, N.; Regina, A. Profiling of 2-Acetyl-1-Pyrroline and Other Volatile Compounds in Raw and Cooked Rice of Traditional and Improved Varieties of India. Foods 2021, 10, 1917. [CrossRef]

23. Xie, Q.; Xu, B.; Xu, Y.; Yao, Z.; Zhu, B.; Li, X.; Sun, Y. Effects of Different Thermal Treatment Temperatures on Volatile Flavour Compounds of Water-Boiled Salted Duck after Packaging. LWT 2022, 154, 112625. [CrossRef]

24. Zhang, R.; Tang, C.C.; Jiang, B.Z.; Mo, X.Y.; Wang, Z.Y. Optimization of Hs-Spme for Gc-Ms Analysis and Its Application in Characterization of Volatile Compounds in Sweet Potato. Molecules 2021, 26, 5808. [CrossRef]

25. Cai, J.S.; Zhu, Y.Y.; Ma, R.H.; Thakur, K.; Zhang, J.G.; Wei, Z.J. Effects of Roasting Level on Physicochemical, Sensory, and Volatile Profiles of Soybeans Using Electronic Nose and Hs-Spme-Gc-Ms. Food Chem. 2021, 340, 127880. [CrossRef]

26. Yin, X.Y.; Lv, Y.C.; Wen, R.X.; Wang, Y.; Chen, Q.; Kong, B.H. Characterization of Selected Harbin Red Sausages on the Basis of Their Flavour Profiles Using Hs-Spme-Gc/Ms Combined with Electronic Nose and Electronic Tongue. Meat Sci. 2021, 172, 108345. [CrossRef]

27. Hu, X.; Lu, L.; Guo, Z.; Zhu, Z. Volatile Compounds, Affecting Factors and Evaluation Methods For Rice Aroma: A Review. Trends Food Sci. Technol. 2020, 97, 136-146. [CrossRef]

28. Adelina, N.M.; Wang, H.; Zhang, L.; Zhao, Y. Comparative Analysis of Volatile Profiles in Two Grafted Pine Nuts By HeadspaceSpme/Gc-Ms and Electronic Nose As Responses To Different Roasting Conditions. Food Res. Int. 2021, 140, 110026. [CrossRef]

29. Du, H.Z.; Chen, Q.; Liu, Q.; Wang, W.; Kong, B.H. Evaluation of Flavor Characteristics of Bacon Smoked with Different Woodchips By Hs-Spme-Gc-Ms Combined with an Electronic Tongue and Electronic Nose. Meat Sci. 2021, 182, 108626. [CrossRef]

30. Bi, S.; Wang, A.; Wang, Y.; Xu, X.; Luo, D.; Shen, Q.; Wu, J. Effect of Cooking on Aroma Profiles of Chinese Foxtail Millet (Setaria italica) and Correlation with Sensory Quality. Food Chem. 2019, 289, 692-698. [CrossRef]

31. Cao, Z.F.; Liu, Y.; Zhu, H.; Li, Y.S.; Xiao, Q.; Yi, C.P. Effect of Soy Protein Isolate on Textural Properties, Cooking Properties and Flavor of Whole-Grain Flat Rice Noodles. Foods 2021, 10, 1085. [CrossRef]

32. Yang, S.; Hao, N.; Meng, Z.; Li, Y.; Zhao, Z. Identification, Comparison and Classification of Volatile Compounds in Peels of 40 Apple Cultivars by Hs-Spme with Gc-Ms. Foods 2021, 10, 1051. [CrossRef]

33. Mohammed, J.; Belisle, C.E.; Wang, S.; Itle, R.A.; Adhikari, K.; Chavez, D.J. Volatile Profile Characterization of Commercial Peach (Prunus persica) Cultivars Grown in Georgia, Usa. Horticulturae 2021, 7, 516. [CrossRef]

34. Spada, F.P.; Balagiannis, D.P.; Purgatto, E.; Alencar, S.M.; Canniatt-Brazaca, S.G.; Parker, J.K. Characterisation of the Chocolate Aroma in Roast Jackfruit Seeds. Food Chem. 2021, 354, 129537. [CrossRef]

35. Parr, H.; Bolat, I.; Cook, D. Modelling Flavour Formation in Roasted Malt Substrates under Controlled Conditions of Time and Temperature. Food Chem. 2021, 337, 121641. [CrossRef]

36. Erten, E.S.; Cadwallader, K.R. Identification of Predominant Aroma Components of Raw, Dry Roasted and Oil Roasted Almonds. Food Chem. 2017, 217, 244-253. [CrossRef] 
37. Tian, P.; Zhan, P.; Tian, H.; Wang, P.; Lu, C.; Zhao, Y.; Ni, R.; Zhang, Y. Analysis of Volatile Compound Changes in Fried Shallot (Allium Cepa L. Var. Aggregatum) Oil at Different Frying Temperatures By Gc-Ms, Oav, and Multivariate Analysis. Food Chem. 2021, 345, 128748. [CrossRef]

38. Ge, Y.; Li, K.; Xie, C.; Xu, Y.; Shi, C.; Hang, F.; Doherty, W.O.S. Formation of Volatile and Aroma Compounds during the Dehydration of Membrane-Clarified Sugarcane Juice to Non-Centrifugal Sugar. Foods 2021, 10, 1561. [CrossRef]

39. Shen, Y.; Wu, Y.; Wang, Y.; Li, L.; Li, C.; Zhao, Y.; Yang, S. Contribution of Autochthonous Microbiota Succession to Flavor Formation During Chinese Fermented Mandarin Fish (Siniperca chuatsi). Food Chem. 2021, 348, 129107. [CrossRef]

40. Gao, C.; Li, Y.; Pan, Q.; Fan, M.; Wang, L.; Qian, H. Analysis of the Key Aroma Volatile Compounds in Rice Bran During Storage and Processing via Hs-Spme Gc/Ms. J. Cereal Sci. 2021, 99, 103178. [CrossRef]

41. Xu, Z.; Chen, J.; Shi, X.; Wang, B.; Zheng, X.; Zheng, X. Characteristic Physicochemical Indexes and Flavor Compounds in Xinjiang Kazak Cheese During Ripening. Food Biosci. 2020, 35, 100586. [CrossRef]

42. Xu, Y.; Zhang, D.; Chen, R.; Yang, X.; Liu, H.; Wang, Z.; Hui, T. Comprehensive Evaluation of Flavor in Charcoal and ElectricRoasted Tamarix Lamb by Hs-Spme/Gc-Ms Combined with Electronic Tongue and Electronic Nose. Foods 2021, $10,2676$. [CrossRef]

43. Feng, X.; Wang, H.; Wang, Z.; Huang, P.; Kan, J. Discrimination and Characterization of The Volatile Organic Compounds In Eight Kinds of Huajiao with Geographical Indication of China Using Electronic Nose, Hs-Gc-Ims and Hs-Spme-Gc-Ms. Food Chem. 2021, 375, 131671. [CrossRef]

44. Su, D.; He, J.-J.; Zhou, Y.-Z.; Li, Y.-L.; Zhou, H.-J. Aroma Effects of Key Volatile Compounds In Keemun Black Tea at Different Grades: Hs-Spme-Gc-Ms, Sensory Evaluation, and Chemometrics. Food Chem. 2021, 373, 131587. [CrossRef]

45. Yao, W.; Cai, Y.; Liu, D.; Chen, Y.; Li, J.; Zhang, M.; Chen, N.; Zhang, H. Analysis of Flavor Formation During Production of Dezhou Braised Chicken Using Headspace-Gas Chromatography-Ion Mobility Spec-Trometry (Hs-Gc-Ims). Food Chem. 2022, 370, 130989. [CrossRef]

46. Akkad, R.; Buchko, A.; Johnston, S.P.; Han, J.; House, J.D.; Curtis, J.M. Sprouting Improves The Flavour Quality of Faba Bean Flours. Food Chem. 2021, 364, 130355. [CrossRef]

47. Sanchez-Zapata, E.; Fernandez-López, J.; Perez-Alvarez, J.A.; Soares, J.; Sousa, S.; Gomes, A.M.P.; Pintado, M.M.E. In Vitro Evaluation of "Horchata" Co-Products as Carbon Source for Probiotic Bacteria Growth. Food Bioprod. Process. 2013, 91, $279-286$. [CrossRef] 